\title{
IR 85-3251
}

\section{A 21205983449}

sкy Luminance and Direct Beam Illuminance

S. Treado

W. Remmert

J. Bean

U.S. DEPARTMENT OF COMMERCE

National Bureau of Standards

National Engineering Laboratory

Center for Building Technology

Gaithersburg, MD 20899

February 1986

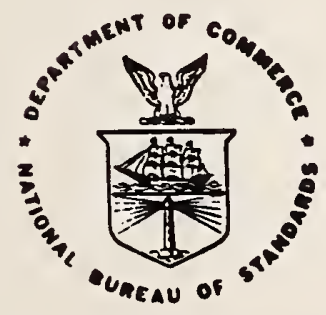

U.S. DEPARTMENT OF COMMERCE

NATIONAL BUAEAU OF STANDARDS

$-Q C$

100

.456

$85-3251$

1986

C. 3 

J. Bean

U.S. DEPARTMENT OF COMMERCE

National Bureau of Standards

National Engineering Laboratory

Center for Building Technology

Gaithersburg, MD 20899

February 1986

U.S. DEPARTMENT OF COMMERCE, Malcolm Baldrige, Secretary NATIONAL BUREAU OF STANDARDS, Ernest Ambler, Director 

Measurements of sky illuminance, sky luminance, direct beam 1lluminance and direct beam irradiance are analyzed and discussed. The database consisted of an annual set of averaged hourly measurements made at the National Bureau of Standards, Galthersburg, Maryland $\left(77^{\circ}\right.$ west longitude, 39.1 $1^{\circ}$ north latitude). The relationship between diffuse sky illuminance and luminance of selected portions of the sky dome is examined. Measured sky luminances are compared to luminances calculated using equations for three standard sky types - clear, partly cloudy and overcast. The percentages of diffuse and direct beam to total illuminance and irradiance incident upon a surface are presented for four vertical orientations and a horizontal orientation. This analysis enables evaluation of the relative daylighting potential of diffuse and direct daylighting and solar heating strategies.

The results indicate that the luminance distribution of actual skies varies considerably from the standard skies. The percentage of global illuminance which was direct beam was greatest for a south-facing surface ( 51 percent) and ranged from approximately 49 percent for a horizontal surface to less than 6 percent for a north-facing surface.

Keywords: Daylighting, diffuse radiation, direct beam radiation, illuminance, irradiance, luminance, sky condition 


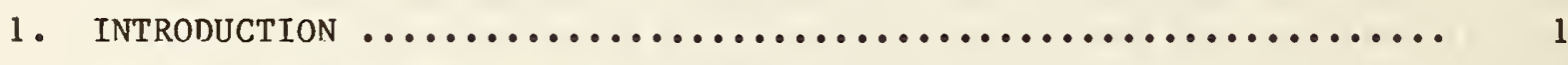

2. DESCRIPTION OF MEASUREMENTS ........................... 2

3. RESULTS $\ldots \ldots \ldots \ldots \ldots \ldots \ldots \ldots \ldots \ldots \ldots \ldots \ldots \ldots \ldots \ldots \ldots \ldots \ldots \ldots \ldots \ldots$

3.1 Sky Luminance $\ldots \ldots \ldots \ldots \ldots \ldots \ldots \ldots \ldots \ldots \ldots \ldots \ldots \ldots \ldots \ldots \ldots$

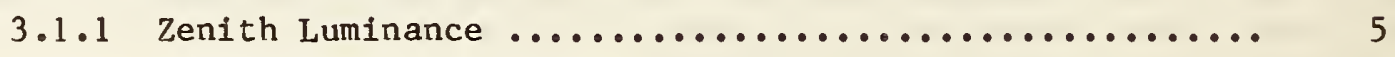

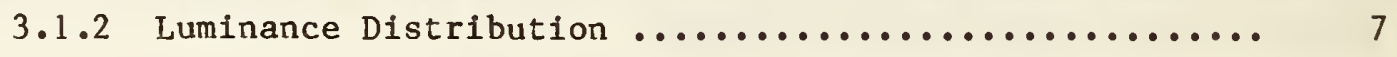

3.2 Direct Beam Illuminance and Irradiance ............... 9

4. ConCLUSions $\ldots \ldots \ldots \ldots \ldots \ldots \ldots \ldots \ldots \ldots \ldots \ldots \ldots \ldots \ldots \ldots \ldots \ldots \ldots \ldots \ldots$

5. REFERENCES ...................................... 13 
LIST OF TABLES

$\underline{\text { Page }}$

Table 1. Determination of Sky Condition .................... 6

Table 2. Zenith Luminance (y) versus diffuse horizontal illuminance

$(x)$ as a function of sky type and solar altitude ..........

Table 3. Point luminance factor ( $y$ ) as a function of cloud ratio

$(x)$ - best fit regression equations ....................

Table 4. Totals and percentages of direct and diffuse illuminance and irradiance $\ldots \ldots \ldots \ldots \ldots \ldots \ldots \ldots \ldots \ldots \ldots \ldots \ldots \ldots \ldots \ldots$ 
LIST OF FIGURES

$\underline{\text { Page }}$

Figure 1. Luminance sensor array $\ldots \ldots \ldots \ldots \ldots \ldots \ldots \ldots \ldots \ldots \ldots \ldots$

Figure 2. Zenith luminance factor as a function of cloud ratio (CR)

Figure 3. Zenith luminance factor as a function of atmospheric

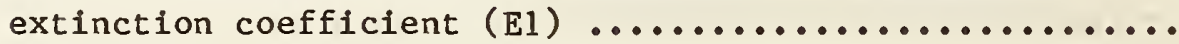

Figure 4. Zenith luminance (LZ) as a function of diffuse horizontal

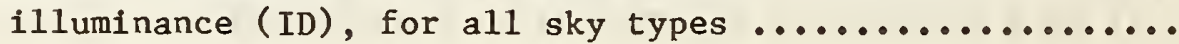

Figure 5. Zenith luminance (LZ) as a function of diffuse horizontal illuminance (ID) for apparent clear skies .............

Figure 6. Zenith luminance (LZ) as a function of diffuse horizontal illuminance (ID) for apparent partly cloudy skies .......

Figure 7. Zenith luminance (LZ) as a function of diffuse horizontal illuminance (ID) for apparent overcast skies ...........

Figure $8 \mathrm{a}$. Zenith luminance (LZ) versus diffuse horizontal illuminance for apparent clear skies, low solar altitude ........

Figure $8 \mathrm{~b}$. Zenith luminance (LZ) versus diffuse horizontal illuminance for apparent clear skies, medium solar altitude .....

Figure 8c. Zenith luminance (LZ) versus diffuse horizontal illuminance for apparent clear skies, high solar altitude ......

Figure 9a. Zenith luminance (LZ) versus diffuse horizontal illuminance for apparent partly cloudy skies, low solar altitude

Figure 9b. Zenith luminance (LZ) versus diffuse horizonta1 illuminance for apparent partly cloudy skies, medium solar

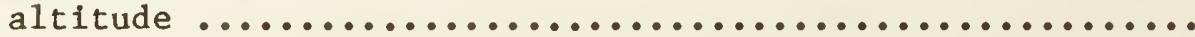

Figure 9c. Zenith luminance (LZ) versus diffuse horizontal illuminance for apparent partly cloudy skies, high solar altitude

Figure 10a. Zenith luminance (LZ) versus diffuse horizontal illuminance for apparent overcast skies, low solar altitude .....

Figure 10b. Zenith luminance (LZ) versus diffuse horizontal illuminance for apparent overcast skies, medium solar altitude ..

Figure 10c. Zenith luminance (LZ) versus diffuse horizontal illuminance for apparent overcast skies, high solar altitude .... 


\section{LIST OF FIGURES (COn't。)}

$\underline{\text { Page }}$

Figure 11. North luminance ratio as a function of cloud ratio ....... 31

Figure 12. North luminance ratio as a function of atmospheric

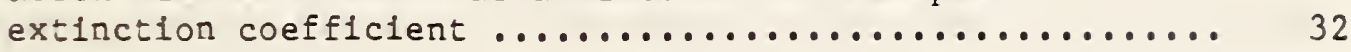

Figure 13. East luminance ratio as a function of cloud ratio ....... 33

Figure 14. East luminance ratio as a function of atmospheric extinction coefficient .......................... 34

F1gure 15. South luminance ratio as a function of cloud ratio ...... 35

Figure 16. South luminance ratio as a function of atmospheric extinction coefficient ......................... 36

Figure 17. West luminance ratio as a function of cloud ratio ....... 37

P1gure 18. West luminance ratio as a function of atmospheric extinction coefficient ......................... 38

Figure 19. North point luminance factor as a function of cloud ratio. 39 Figure 20. East point luminance factor as a function of cloud ratio. 40 Pigure 21. South polnt luminance factor as a function of cloud ratio. 41 Figure 22. West point luminance factor as a function of cloud rat1o. 42 



\section{INTRODUCTION}

Many studies have demonstrated the effectiveness of daylight utilization in minimizing the energy requirements for bullding lighting and space cooling, and in many cases, total annual bullding energy requirements [1-5]. Effect1ve daylighting design requires consideration of many factors, including illumination and visibility requirements, thermal and solar control strategies, occupant comfort, and integration of the fenestration with the bullding envelope and HVAC system. Procedures have been developed for calculating interior illuminance levels and incorporating the effect of daylighting on bullding energy requirements into the overall building design procedure. Some of these procedures are single-point, design day type techniques, while others attempt to determine seasonally adjusted daylighting effects [6-8]. The computer simulation of annual bullding energy use on an hourly basis has been used extensively to evaluate the energy impact of daylighting $[9,10]$.

The common starting point for almost all daylighting calculation procedures is the specification of the sky and solar conditions. These include some combination of 1rradiances, illuminances and luminances. Various correlations are used to assemble the conditions needed for the daylighting calculation from the avallable information. While most daylighting predictions require sky luminance or 1lluminance data, this information is usually only avallable for some standard sky conditions or limited time sequence. The weather information available to hourly building energy simulation computer programs consists largely of solar radiation levels, either direct beam and diffuse on a horizontal surface or some other related combination [11]. Luminous efficacy values are used to convert from irradiance to flluminance, and luminance distribution equations are used to predict the sky luminance distribution assoclated with the actual weather conditions [12]. Luminance distribution equations are a means to extrapolate from a concise weather description to a complete sky luminance distribution. Once the sky luminance distribution is known, it is relatively easy to complete the interior 1lluminance calculation, since that requires standard radiation exchange computations. The major difficulty lies in determining the actual sky luminance distribution.

As a step towards examining the luminance distribution of actual skies, the measured luminances of five portions of the sky are analyzed. The luminance of each 15 degree fleld-of-view of the sky is compared to zenith luminance and horizontal diffuse 1lluminance. The ratio of zenith luminance to horizontal diffuse luminance is known as the zenith luminance factor, while the ratio of the luminance at some sky point to the zenith luminance is known as the point luminance factor, which is comparable to the solution of a luminance distribution equation for some instant in time. The influence of sky condition and solar position on these ratios is examined, and the ratios are compared to predicted values generated from equations for standard skies.

Another important daylighting issue is the potential usefulness of direct beam 11lumination in providing interior daylight. In some calculation procedures, direct beam daylight is assumed to be blocked by a shading device; in other 
cases the direct beam daylight is included in the calculations. While daylighting with direct beam illumination usually requires a special fenestration design (light shelves, light pipes, reflectors), the daylighting potential of direct beam utilization for a particular orientation can be examined by comparing the relative magnitudes of the direct beam and diffuse components of the 111 uminance incident upon a surface for that orientation. Examination of the available direct beam illumination levels enables the determination of the maximum potential daylighting benefits of direct beam utilization. 


\section{DESCRIPTION OF MEASUREMENTS}

The measurement data were collected at the NBS Daylighting Laboratory in Galthersburg, Maryland (suburb of Washington, D.C., $77^{\circ}$ west longitude, $39.1^{\circ}$ north latitude). As part of a larger data collection program, the following luminance, illuminance and irradiance measurements were made.

a) Sky Luminance - Using photovoltaic silicon cells with photometric filters and a $15^{\circ}$ field-of-view, measurements were made for five areas of the sky, centered on zenith and $42^{\circ}$ elevation due north, east, south and west. A photograph of the luminance sensor array is shown in Figure 1.

b) Illuminance - Using photovoltaic silicon cells with photometric filters and cosine diffusers with hemispherical field-of-view, measurements were made for five orientations, namely horizontal and north, east, south and westfacing vertical surfaces. Diffuse horizontal illuminance was measured using a shading band.

c) Irradiance - Using photovoltaic silicon cells with radiometric filters and cosine diffusers with hemispherical field-of-view for vertical orientations, and thermopile-type pyranometers for horizontal orientations, measurements were made for five orientations, namely irradiance for horizontal and north east, south and west-facing vertical surfaces. Diffuse horizontal irradiance was measured using a shading band.

A complete description of the measurement system and uncertainty analysis can be found in a previous report [13]. The data analyzed in this report consist of average hourly values, based on multiple readings during each hour, for a composite, one-year period, assembled from measurements made in 1982, 1983 and 1984, with the bulk of the data being from the first two years. The estimated maximum measurement uncertainty is $\pm 3 \%$ for luminance, $\pm 8 \%$ for vertical irradiance, $\pm 3 \%$ for vertical and global horizontal illuminance, $\pm 5 \%$ for diffuse horizontal illuminance, $\pm 4 \%$ for global horizontal irradiance and $\pm 6 \%$ for diffuse horizontal irradiance. 


\section{RESULTS}

\subsection{SKY LUMINANCE}

The illuminance at a particular point on a surface is determined by the luminance pattern of the surrounding environment. Thus, for an exposed exterior horizontal surface, the luminance of the sky dome controls the illuminance at the surface. Since, in most instances, the sky luminance is non-uniform, the contribution of each portion of the sky must be separately determined and the results combined to obtain the illuminance on the surface. This type of calculation involves the luminance (or related existance) of the particular portion of the sky, and an area integral involving the geometry relating the portion of the sky and the point on the surface.

Formulas have been developed to model the luminance distribution of standard skies. A standard clear sky distribution function was developed by Kittler and adopted by the CIE in 1973 [14]. Moon and Spencer developed an empirical relation for a standard overcast sky, which was adopted by the CIE in 1955 [15]. Pierpoint developed a luminance distribution equation for partly cloudy skies in a form similar to the clear sky distribution [16]. For the standard overcast sky the ratio of point luminance to zenith luminance is assumed to be a function of the elevation of the sky point only. The partly cloudy and clear equations also include the angle between the sun and the sky points. The important fact is that if the sky is assumed to conform to one of the standard luminance distributions, a unique relationship exists between zenith luminance (LZ) and diffuse horizontal illuminance (Ed), and between point luminance and zenith luminance, for any fixed set of solar and point angles. The ratio of zenith luminance to diffuse horizontal illuminance is frequently called the zenith luminance factor ( $\mathrm{ZL}$ ), while the ratio of point luminance to zenith luminance is equivalent to the solution of the luminance distribution equation for that set of sun and point angles (point luminance factor PL). Thus, for standard skies, luminance at a sky point is related to diffuse horizontal illuminance by the product of the zenith luminance factor and the point luminance factor. For convenience, this product has been labeled the combined luminance factor (CL).

Actual skies rarely correspond to standard skies, due to random cloud patterns and mixed sky conditions. However, the exact prediction of luminance distributions of dynamic real skies is significantly beyond the reach of current measurement and modeling capabilities. If sky luminance values are being used to evaluate the daylighting performance of fenestration systems, what is required is a 'fair' method of comparing design options on a consistent basis. Thus, if it is not possible to predict the exact sky luminance distributions over a time interval such as a year, an acceptable substitute would be a set of sky luminance values which are representative of the actual luminances in the manner with which they influence the daylighting performance of fenestration systems.

To address the issue of the relationship between the illuminance and sky luminance distribution of actual skies, and their comparison with standard sky luminance distributions, the measured sky luminance and illuminance data were analyzed. The measured zenith luminance factors were determined by the ratio 
of zenith luminance to diffuse horizontal illuminance; the measured point luminance factors were determined by the ratio of each of the point luminances to the zenith luminance and the combined luminance factors were determined from the ratio of point luminance to diffuse horizontal illuminance. Although the individual luminance measurements are described as being point luminances, they actually represent a finite area encompaged by a $15^{\circ}$ field of view.

\subsubsection{Zenith Luminance}

Figure 2 presents zenith luminance factor as a function of cloud ratio (defined as diffuse horizontal irradiance divided by global horizontal irradiance). Figure 3 is a similar plot with atmospheric extinction coefficient as the abscissa. These figures demonstrate the range in zenith luminance factor values which occurred during the year. By comparison, for solar altitudes less than 75 degrees, the zenith luminance factors for the standard skies range from 0.144 to 0.540 for the clear sky, to 0.201 to 0.456 for the partly cloudy sky, to a constant .409 for the overcast sky. (These zenith luminance factors are multiplied by $\pi$ for conventional units of footcandle and foot lambert). In figures 2 and 3 apparent overcast skies are represented by cloud ratios near one or extinction coefficients near six. The term apparent is used because extinction coefficient is determined by the level of direct beam irradiance and thus gives no information about the remainder of the sky dome, and cloud ratio is determined by the horizontal diffuse and direct irradiances, which are not explicit indicators of sky condition.

While extinction coefficient and cloud ratio are not explicit indicators of sky condition, they are frequently the only parameters related to sky condition which are available when attempting to reconstruct the luminance distributions of the sky vault from standard weather data. In lieu of direct measurements of sky luminance distribution, an estimate of sky condition followed by a prediction of the associated sky luminance distribution are the only avenues avai1able for the daylighting designer.

A considerable range in zenith luminance factor values is seen for the apparent overcast skies as compared to the standard overcast sky.

For the clear and partly cloudy sky conditions, represented by the low and moderate cloud ratios and extinction coefficients, considerable variation in zenith luminance factors would be expected, due to the dependence on solar altitude. This expected result is evident in the figures.

In order to examine in greater detail the relationship between zenith luminance and diffuse horizontal illuminance, and the influence of sky condition and solar altitude on the zenith luminance factor, a series of plots was generated displaying zenith luminance as a function of diffuse horizontal illuminance for various ranges of solar altitude and atmospheric extinction coefficient. Figure 4 presents zenith luminance as a function of diffuse illuminance for all of the data points. The slope of the line connecting each data point with the origin is equal to the zenith luminance factor. Figures 5, 6 and 7 show the data from figure 4 subdivided into apparent sky condition types clear, partly cloudy and overcast, respectively. The determination of apparent sky condition was based 
on the measured extinction coefficient according to the following table.

Table 1

Determination of Sky Condition

Range of Extinction Coefficient (E1)

$$
\begin{array}{rl}
\mathrm{E} 1 & \leq 0.4 \\
0.4 & \mathrm{E} 1 \leq 1.6
\end{array}
$$

Assumed Sky Type

Clear

Partly Cloudy

Overcast

These figures illustrate several points. For apparent clear skies, figure 5, zenith luminance tends to follow two bands. One band has a low slope, meaning low zenith luminance factor, while the second band has a steep slope and a corresponding large zenith luminance factor. The probable explanation for this behavior is associated with the difficulty in determining the sky condition simply on the basis of the direct beam illuminance, which is used to compute the atmospheric extinction coefficient. The restriction of low extinction coefficient allows partly cloudy sky data to be included with the actual clear sky data, if the sun is not obstructed by clouds. Thus the high zenith luminance values in figure 5 are probably due to overhead clouds occuring in an otherwise clear sky. Isolated overhead clouds would be brighter than clear blue sky. The low zenith luminance values are probably more uniformly clear.

Figure 6 presents similar data for partly cloudy skies. A significant amount of spread is seen in the data, with generally larger zenith luminance factors than for clear skies. The overcast sky data are shown in figure 7 . This figure shows a clear trend of high zenith luminance factors, with the typical values for the apparent overcast skies being approximately 50 percent greater than for the standard overcast sky. A comparison of figures 5, 6 and 7 shows that the data for the partly cloudy skies are bounded by the clear and overcast sky data.

Some of the scatter in figures 6 and 7 can be explained by considering the effect of solar altitude in addition to the effect of sky condition. When the solar disk is at least partly visible, as is the case for clear and partly cloudy skies, for a fixed level of diffuse llluminance the zenith luminance is greater if the solar altitude is greater. Examination of the zenith luminance factors for the standard clear and partly cloudy sky shows that for solar altitudes less than 30 degress the zenith luminance factors are fairly constant. Three ranges of solar altitude were chosen, namely 20 to 30 degrees, 30 to 50 degrees and greater than 50. Solar altitudes less than 20 degrees were excluded to control measurement uncertainty associated with the determination of diffuse horizontal illuminance and atmospheric extinction coefficient. Very few solar altitudes exceeded 70 degrees.

The relationship between zenith luminance and diffuse horizontal illuminance as a function of solar altitude and sky condition is shown in figures $8 \mathrm{a}, \mathrm{b}$ and $\mathrm{c}$ for clear skies, figures $9 a, b$ and c for partly cloudy skies and figures 10a, $b$ and $c$ for overcast skies. The effect of solar altitude is particularly 
apparent for clear skies in figure 8c. Also plotted on the figures are lines corresponding to the standard skies at the extremes of the solar altitude range, the linear best fit through the measured data points and the linear best fit for the measured data forced through zero. In actuality, zenith luminance must be zero when diffuse horizontal 11 luminance is zero. The measured and standard sky zenith luminances are in fairly good agreement for low solar altitudes, figure $8 \mathrm{a}$, although a significant number of measured values are less than the minimum expected according to the standard sky relations. In figure $8 \mathrm{~b}$, more scatter is seen in the measurements, and the best-fit-through-zero line is bracketed by the standard sky 1ines. However, the majority of the measurements fall below the standard sky ranges, with a smaller number of high luminance readings causing the slope of the best-fit-through-zero line to be greater than otherwise would have occurred. The high luminance measurements are probably due to non-clear sky conditions near zenith. (1.e., white clouds instead of blue sky). The same effects are seen in figure $8 \mathrm{c}$ for the high solar altitude range. The greatest variations are expected in this range, and the best-fit-throughzero line is less than the standard sky range.

The partly cloudy skies, figures $9 a, b$ and $c$, exhibit the greatest variation, both in the magnitudes of the zenith luminances, and the comparison of the measurements to the standard skies. However, the best-fit-through-zero lines do fall within or near the standard sky ranges. The large variations are probably due to the uncertain nature of the partly cloudy sky, where random cloud patterns produce unpredictable luminance distributions.

The overcast skies, figures $10 \mathrm{a}, \mathrm{b}$ and $\mathrm{c}$, are the most predictable, and exhibit the least scatter of the three sky types. By definition, the ratio of zenith luminance to diffuse horizontal illuminance is a constant ( 0.409 for SI units). The measured zenith luminances are almost always less than the standard sky values, with the slope of the best-fit-through-zero 1 ines being 44 to 26 percent lower than the standard sky 1 ines.

The equations for the standard sky and regression fit lines are 1isted in Table 2 .

Table 2

Zenith Luminance $(y)$ versus diffuse horizontal illuminance $(x)$ as a function of sky type and solar altitude

Atmospheric

Extinction

Coefficient

$<0.4$

$<0.4$

$<0.4$

0.4 to 1.6

0.4 to 1.6

0.4 to 1.6

$>1.6$

$>1.6$

$>1.6$
Solar Altitude Range

20 to $30^{\circ}$

30 to $50^{\circ}$

$>50^{\circ}$

20 to $30^{\circ}$

30 to $50^{\circ}$

$>50^{\circ}$

20 to $30^{\circ}$

30 to $50^{\circ}$

$>50$
Standard Sky

Low Range High Range

$0.142 \mathrm{x}$

$0.156 \mathrm{x}$

$0.234 \mathrm{x}$

$0.214 \mathrm{x}$

$0.230 \mathrm{x}$

$0.292 x$

$0.409 x$

$0.409 x$

$0.409 x$
$0.156 \mathrm{x}$

$0.234 \mathrm{x}$

$0.540 \mathrm{x}$

$0.230 x$

$0.292 x$

$0.456 x$

$0.409 x$

$0.409 x$

$0.409 x$
Best Fit

through Zero unforced

$0.118 x$

$305+0.0943 x$

$0.190 x$

$0.400 x$

$0.186 \mathrm{x}$

$0.213 x$

$0.297 x$

$0.232 x$

$0.260 x$

$0.301 x$ 3040-0.0268x

$4012+0.162 x$

$1352+0.115 x$

$2112+0.134 x$

$5681+0.117 x$

$1033+0.168 x$

$1279+0.206 x$

$2028+.237 x$ 


\subsubsection{Luminance Distribution}

Some of the aspects of sky luminance distribution were investigated by analyzing luminance measurements of five 15 degree field-of-view portions of the sky dome. These five locations consisted of zenith and north, east, west and south-facing luminances, although the measurement represents an average luminance over a discrete portion of the sky). The ratio of point luminance to zenith luminance (the equivalent of the solution to a luminance distribution equation at some instant in time) is examined as a function of sky condition by plotting the measured luminance ratios against cloud ratio and atmospheric extinction coefficient. Luminance ratios are plotted only when no direct beam radiation was incident upon a vertical surface facing the same direction as the luminance sensor.

The ratio of north luminance to zenith luminance is presented as a function of cloud ratio in figure 11 , and as a function of atmospheric extinction coefficient in figure 12. The vast majority of the luminance ratios are less than two, with no observable variation with cloud ratio. The variations in luminance ratio values are due to differences in solar position and sky condition. There is no convenient comparison of predicted versus measured luminance ratios, since the standard luminance distribution equations would have to be solved for the exact solar position and sky type to compare against each measured value. However, it is clear that the measured luminance ratios do not vary widely. In figure 12, the luminance ratios exhibit the greatest variation for low atmospheric extinction coefficient values, and remain within a fairly narrow band for extinction coefficients between two and five, before showing greater variation at an extinction coefficient of six. It should be noted that due to the nature of the exponential relationship between direct beam irradiance and atmospheric extinction coefficient, values can extend out to infinity. All extinction coefficients greater than six were set to that value, so the luminance ratios at extinction coefficient of six actually include values which would have been plotted off of the graph.

The luminance ratios for the other three orientations are very similar to north. The ratio of east point luminance to zenith luminance is plotted in figure 13 as a function of cloud ratio, and in figure 14 as a function of atmospheric extinction coefficient. South luminance ratios are presented in figures 15 and 16, and west luminance ratios in figures 17 and 18 .

The possibility of linking the luminance of a sky point directly to the diffuse horizontal illuminance was investigated by plotting the ratio of point luminance to diffuse illuminance as a function of cloud ratio. If the ratio of point luminance to diffuse illuminance could be predicted based on solar and sky conditions, the separate determination of zenith luminance and luminance distribution would not be required. The ratio of point luminance to diffuse horizontal illuminance can be termed the point luminance factor. Point luminance factors are plotted in figures 19, 20,21 and 22 for north, east, south and west sky points, respectively. A linear least-squares regression line is also plotted for each figure. Again, this data set excludes measurements taken when direct beam solar radiation was incident upon a vertical surface facing the 
same direction as the sensor. Thus, the data presented represent solar

posttions that are not near sky points, the closest allowable sky point to sun angle being 90 degrees, or overcast sky conditions. Additional analysis would be required to allow inclusion of measurements taken when the solar disk was visible within 90 degrees of the sky point, but not closer than 15 degrees. If the solar disk is visible within the field of view of the luminance sensor, the measurement would not be indicative of sky luminance, but an average sun and sky luminance.

Figures 19 through 22 are similar in appearance, as are the linear best-fit lines. In general, the point luminance factors remain in a narrow range between 0.1 and 0.25 , increasing with higher cloud ratios. The greatest variation occurs for the highest cloud ratios. A linear expression may not be the best way to relate point luminance factor to cloud ratio, since regression lines fall above the measurements in the 0.6 to 0.9 cloud ratio range. Other relations are being pursued. Table 3 lists the equations for the linear best-fit lines from each figure.

Table 3

Point luminance factor ( $y$ ) as a function of cloud ratio $(x)$ best-fit linear regression equation

Sky Point

North

East

South

West
Best Fit to Data

$$
\begin{aligned}
& y=0.0938+0.262 x \\
& y=0.0970+0.264 x \\
& y=0.0876+0.220 x \\
& y=0.0904+0.245 x
\end{aligned}
$$

\subsection{DIRECT BEAM ILLUMINANCE AND IRRADIANCE}

The potential benefits of direct beam daylighting or direct gain passive solar strategies were examined by evaluating the available direct beam illuminance and irradiance for horizontal and vertical surfaces. Direct horizontal illuminance and irradiance were determined from measurements of the diffuse and global horizontal components, by subtracting diffuse from global. Direct beam illuminances and irradiances on north, east, south and west-facing surfaces were determined by computing direct normal from direct horizontal and adjusting for the angles of incidence on the vertical surfaces using the known solar position.

Based on the measurements, annual totals of global, direct and diffuse illuminance $(1 \mathrm{ux} \cdot \mathrm{hr})$ and irradiance $\left(\mathrm{wm}^{-2} \cdot \mathrm{hr}\right)$ were computed. The annual total ratios of direct to global and diffuse to global illuminance and irradiance were also computed. In addition, several hourly averages were computed. For each surface orientation the following ratios were computed, where:

$$
\begin{aligned}
\mathrm{D} & =\text { direct } \\
\mathrm{d} & =\text { diffuse } \\
\mathrm{G} & =\text { global }
\end{aligned}
$$

$\mathrm{D} / \mathrm{G}=\mathrm{direct} / \mathrm{global}$
$\mathrm{D} / \mathrm{A}=\mathrm{direct} / \mathrm{avallable}$
$\mathrm{G} / \mathrm{A}=\mathrm{global} /$ available 

$\mathrm{A}=\mathrm{available}=\mathrm{d}+\mathrm{DN}$
$\mathrm{d} / \mathrm{A}=$ diffuse/available
$\mathrm{DN}=$ direct normal
$\mathrm{d} / \mathrm{G}=\mathrm{d}$ iffuse/global
$\mathrm{D} / \mathrm{DN}=\mathrm{direct/direct} \mathrm{normal}$

Table 4 presents the totals and percentages of direct beam and diffuse 111 uminance and irradiance for horizontal and vertical surfaces. of the annual totals, direct illuminance ranged from 41 percent for west vertical to 51 percent for sourth vertical, except for the north vertical value of less than 6 percent. The similar irradiance percentages were slightly higher. In general, except for the south and north-facing surfaces, the percentage of diffuse illuminance was slightly greater than direct, while the percentage of direct irradiance was slightly greater than diffuse. The south-facing surface direct percentage was 51 for illuminance and 53 for irradiance.

Examination of the annual percentages of direct beam and diffuse sky illuminances and irradiances for Gaithersburg, Maryland area indicates that the daylighting and solar gain potential from direct beam utilization is approximately equal to the potential of diffuse utilization except for a north-facing surface. That is, the total amount of available daylight and sunlight is about half direct beam and half diffuse sky. While it is more difficult to make use of direct beam daylight than diffuse daylight, due to the need to reflect and diffuse the direct beam enabling the daylight to be distributed throughout the interior space, significant potential daylighting benefits from direct beam utilization are apparent. Conversely, half of the available solar energy is diffuse, indicating the importance of designing a solar gain facility to capture both diffuse and direct solar radiation.

Another set of ratios was also calculated for each surface orientation. The annual average hourly ratios, as described above, are shown in Table 4. These differ from the total annual ratios in the following manner. The total annual ratios were determined by summing the hourly values over the year and computing the quotient of the appropriate quantities. The average hourly ratios were determined by computing the appropriate ratio each hour and averaging over the year. The average hourly percentages of direct illuminance and irradiance are less than the corresponding annual total percentages, ranging from 20 to 34 percent, except for the north-facing value of about 6 percent. The direct percent of available illuminance ranges from 12 to 22 percent, except for the north-facing value of about one percent. The diffuse percentage are much greater, ranging from 60 to 96 percent. The reason for the significant differences between the annual total ratios and the annual average hourly ratios is that high direct beam levels occur only a small percentage of the time. Thus the hourly average direct beam contribution is less than the total direct beam contribution, since each hourly ratio is given equal weight in computing the average hourly percentage. The hourly ratios provide a lower bound for direct beam daylighting benefits, since very high daylight levels might cause overillumination, reducing the efficiency of daylight as a light source.

The ratios of direct to direct normal indicate the ability of a particular surface to capture direct normal illuminance and irradiance, by virtue of 1 ts orientation. The horizontal surface captures over 50 percent of the direct normal energy while the remaining surfaces range from three percent (north) to 35 percent (south). For the year, direct normal illuminance was 45 percent of available, and direct normal irradiance was 46 percent of available. 


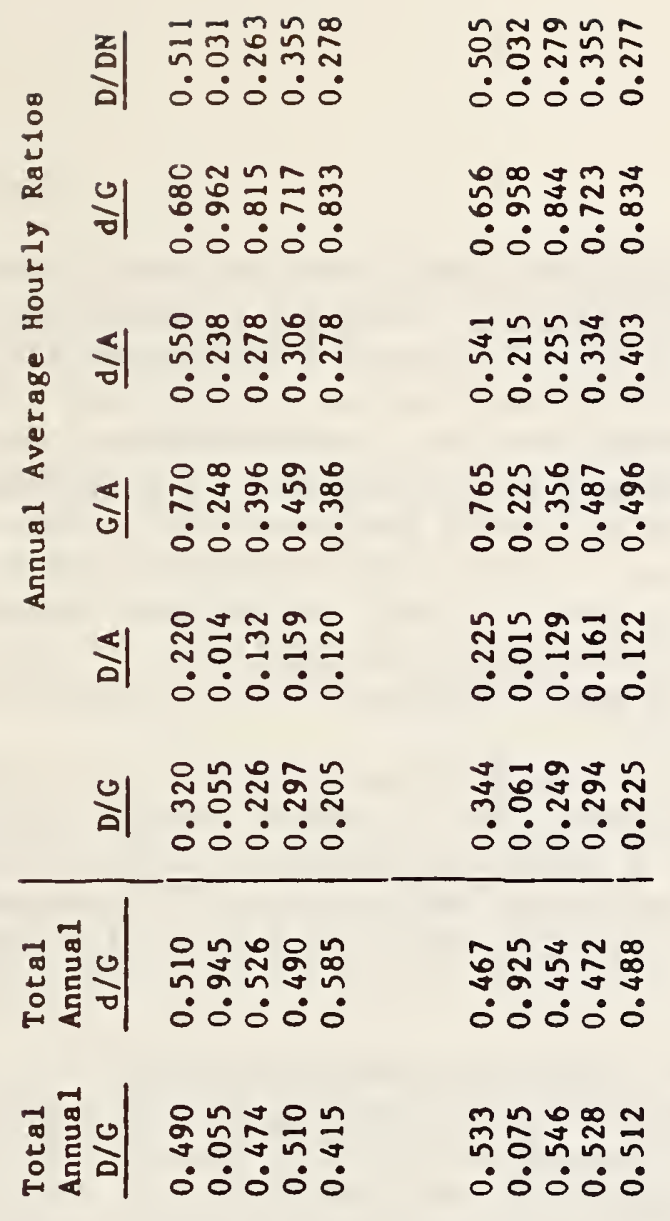

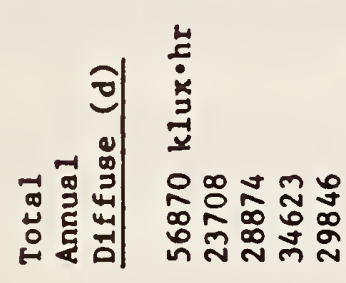

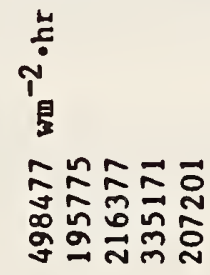
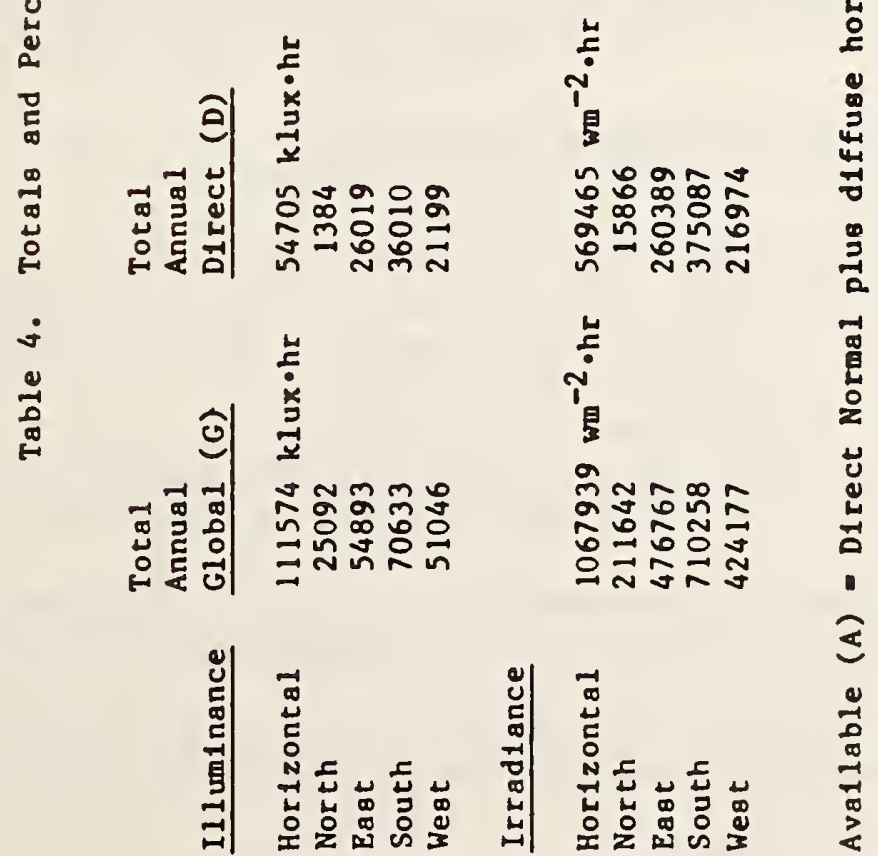
Analysis of measure sky and solar illuminance, luminance and irradiance values over a typical annual period for Washington, D.C. yielded several interesting results. Comparisons of measured sky zenith luminance to standard sky zenith luminance, and their relation to horizontal diffuse sky illuminance, indicate significant differences between real skies and the standard skies. Difficulty in determining sky condition from measurements contributed to some data scatter, but significant variations in the ratio of zenith luminance to diffuse horizontal illuminance occurred in any case. Solar altitude has a strong influence on clear sky zenith luminance. The data for the partly cloudy skies were bounded by the clear and overcast sky data. The overcast sky zenith luminance factors were consistently less than the standard sky value, being 26 to 44 percent lower

The ratios of luminance at four points to zenith luminance (i.e. corresponding to the solutions to a sky luminance distribution equation) did not vary widely, with most values being less than two. A strong correlation with sky type, using cloud ratio as the indicator of sky condition, was observed. Measurements taken when the solar disk was visible near the sky points were excluded from the analysis.

Direct beam illuminance and irradiance constituted approximately one half of the total annual avallable solar energy incident upon horizontal and south, east and west-facing surfaces. The average hourly direct beam percentages were between 20 and 30 percent. These numbers indicate the potential of direct beam daylighting systems, and the importance of diffuse solar energy to passive solar designs. 


\section{REFERENCES}

1. Kusuda, T., Collins, B., Simplified Analysis of Thermal and Lighting Characteristics of Windows - Two Case Studies, National Bureau of

Standards, Building Science Series 109, February 1978.

2. Johnson, R., Selkowitz, S., Winkelman, F., Zentner, M., Glazing Optimization Study for Energy Efficiency in Commerical Office Buildings, Third

International Symposium on Energy Conservation in the Built Environment, Dublin, Ireland, March 1982.

3. Jurovics, S., Daylight, Glazing and Building Energy Minimization, IBM Scientific Center publication, Los Angeles, CA, 1981.

4. Treado, S. and Kusuda, T., Daylighting, Window Management Systems and Lighting Controls, NBSIR 802147 , December 1980 .

5. Treado, S., Fillette, G., and Kusuda, T., Evaluation of the Daylighting and Energy Performance of Windows, Skylights and Clerestories, NBSIR 83-2726, June 1983.

6. Bryan, H., Clear, R., Rosen, J., and Seklowi亡z, S., Quicklite 1: New Procedure for Daylighting Design, Solar Age, August 1981 .

7. Dilaura, D. I. and Hauser, G. A., On Calculating the Effects of Daylighting in Interior Spaces, Journal of the Illuminating Engineering Society, Vol. 7, pp. 2-14, 1978 .

8. CEL-1 Lighting Computer Program - Users Guide, CR 81.026 Naval Civil Engineering Laboratory, Port Hueneme, CA, 1981 .

9. Place, W., Fontoynant, M., Bauman, F., Andersson, B., Howard T., Commercial Building Building Daylighting, LBL0-14348, Lawrence Berkeley Laboratory, Berkeley, CA 94720 , 1982 .

10. Gillette, G., A Daylighting Model for Building Energy Simulation, National Bureau of Standards, Building Science Series 152, March 1983.

11. National Climatic Center, 1976, Tape Reference Manual "Test Reference Year," National Climatic Center, Asheville, N.C., Also published in the ASHRAE Journal, February 1977 , p. 47.

12. Gillette, G., Pierpoint, W., and Treado S., A general 1 lluminance model for daylight avallability," presented at the 1982 IES Technical Conference, Atlanta, GA, August 8-12, 1982 .

13. Treado, S., Gillette, G., Remmert, W., and Beau, J., The NBS Daylight Availability Database, NBSIR 84-2859, March 1984.

14. "Standardization of Iuminance distribution on clear skies," CIE Publicatton No. 22, Commission Internationale de L'Eclaire, Paris, 1973. 
15. "International recommendations for the calculation of natural daylight," CIE Publication No. 16, Commission Internationale de L'Eclaire, Paris, 1970.

16. Pierpoint, W., "A simple sky model for daylighting calculations," presented at the 1983 International Daylighting Conference, Phoenix, February 16-18, 1983. 


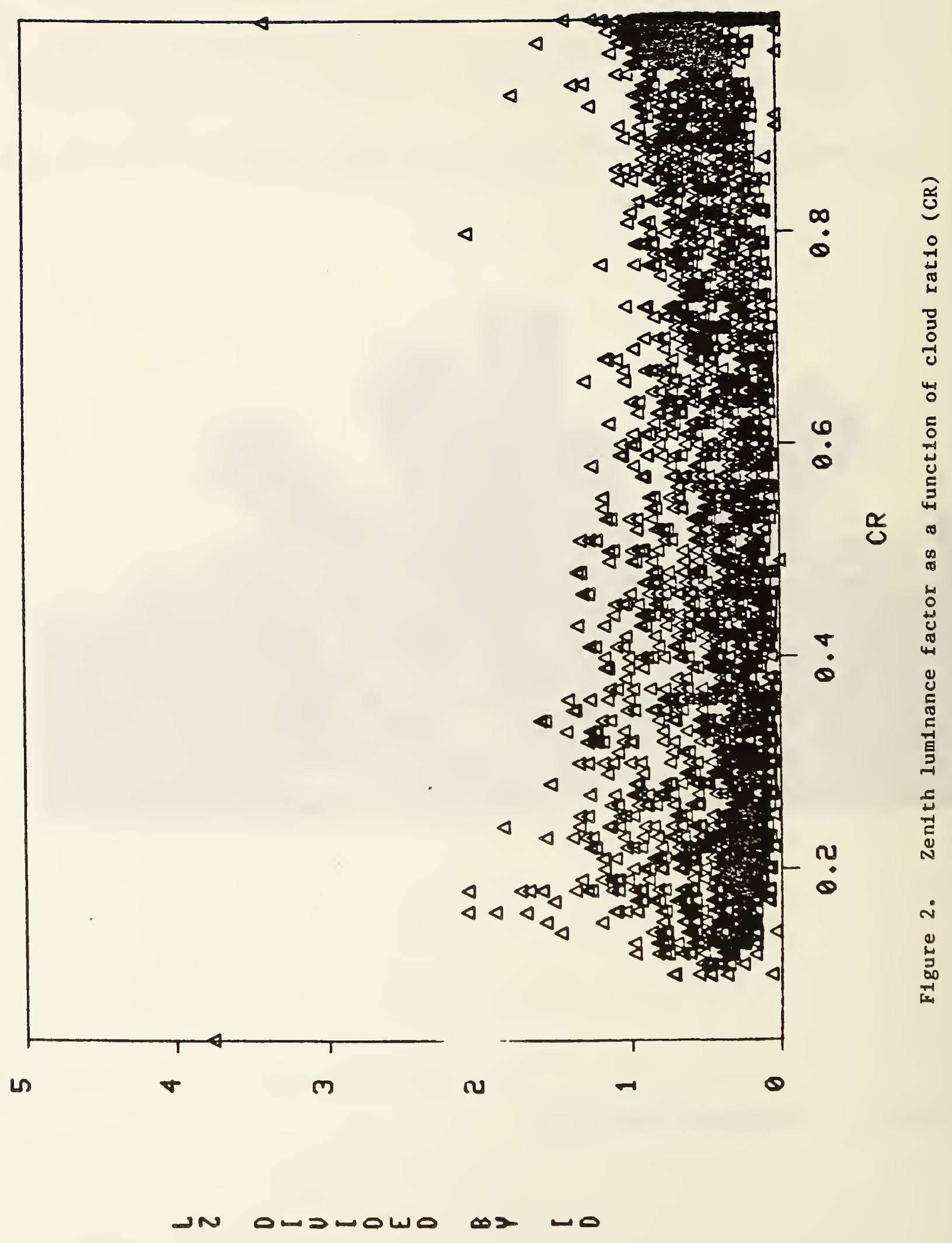




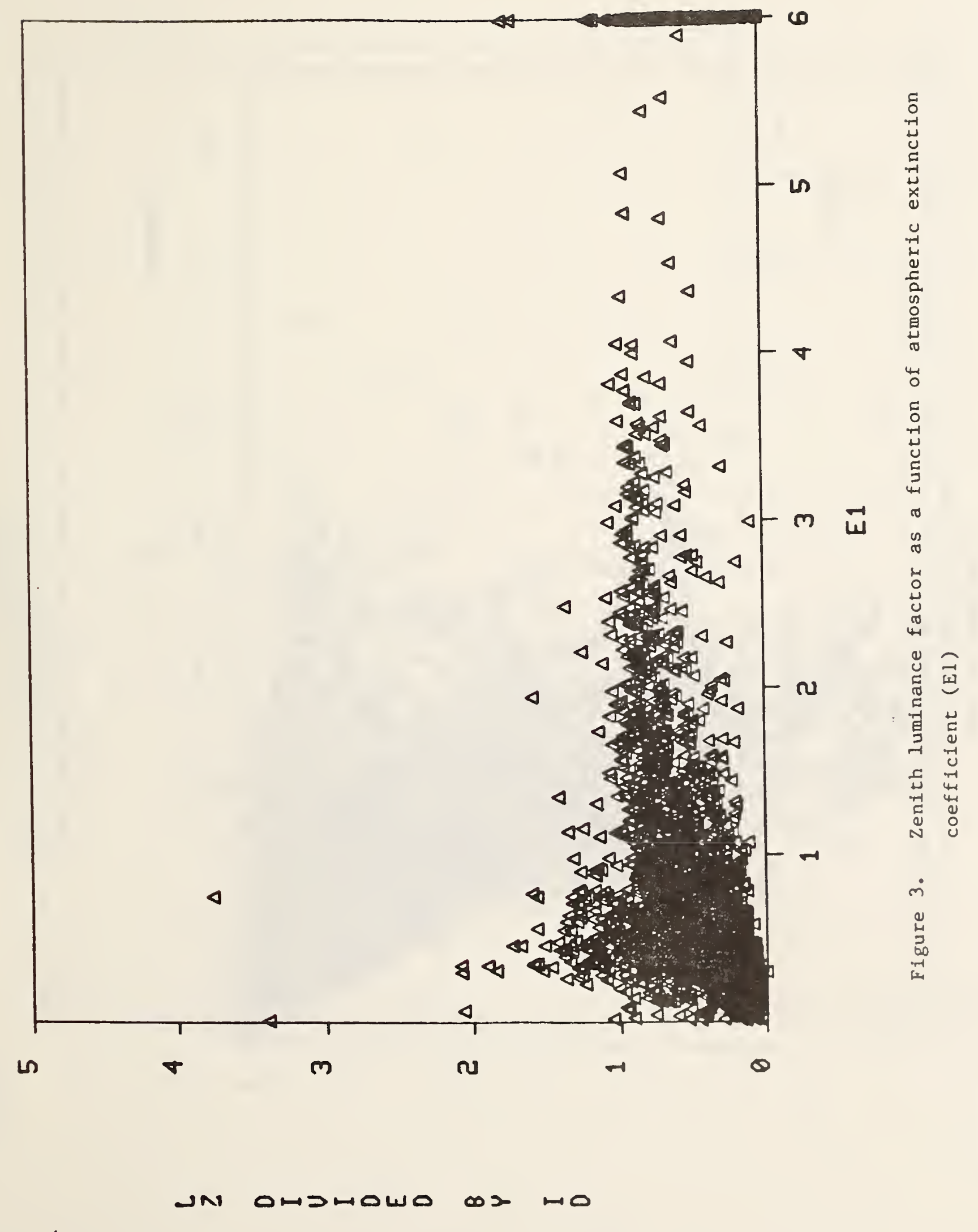




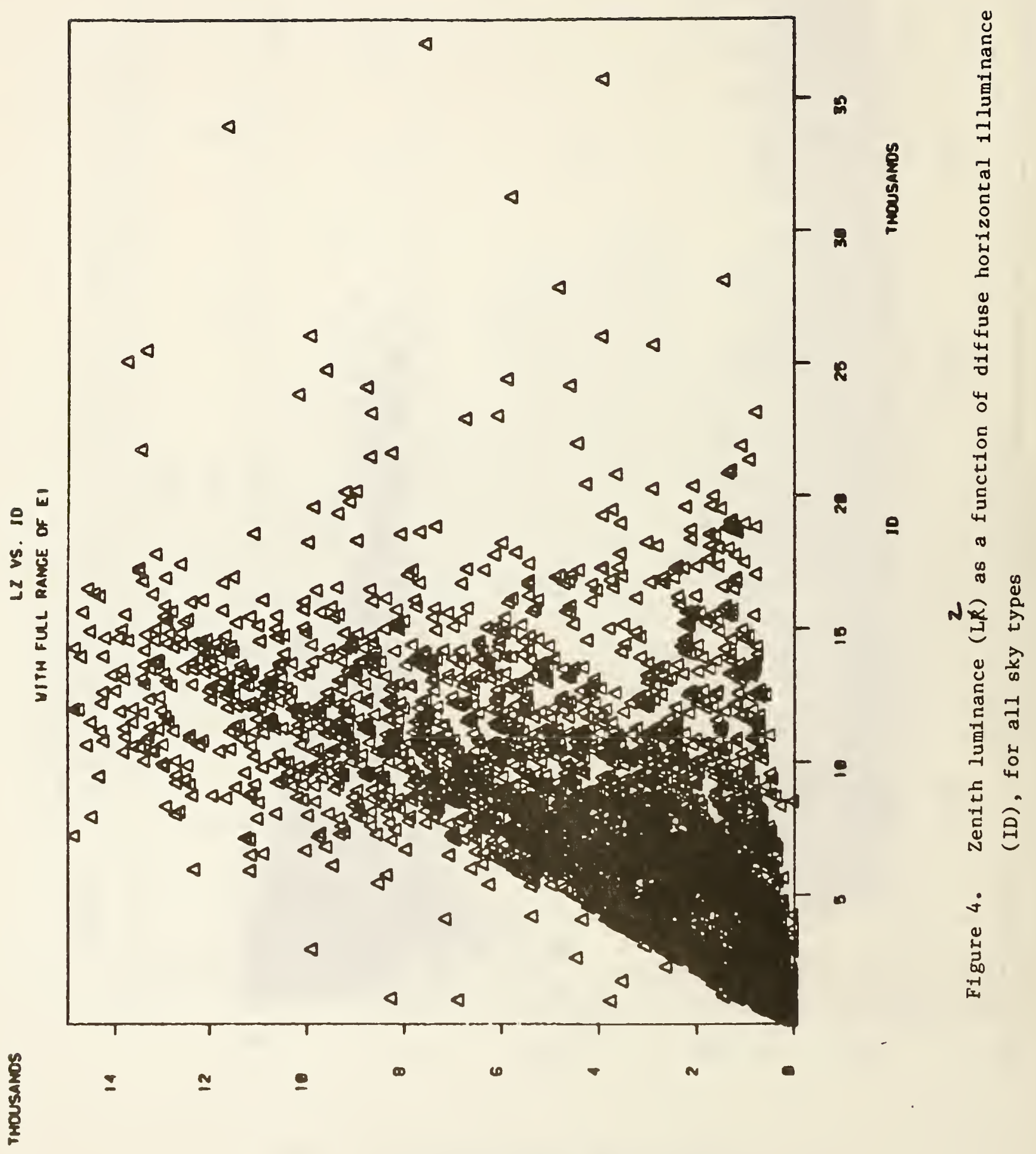




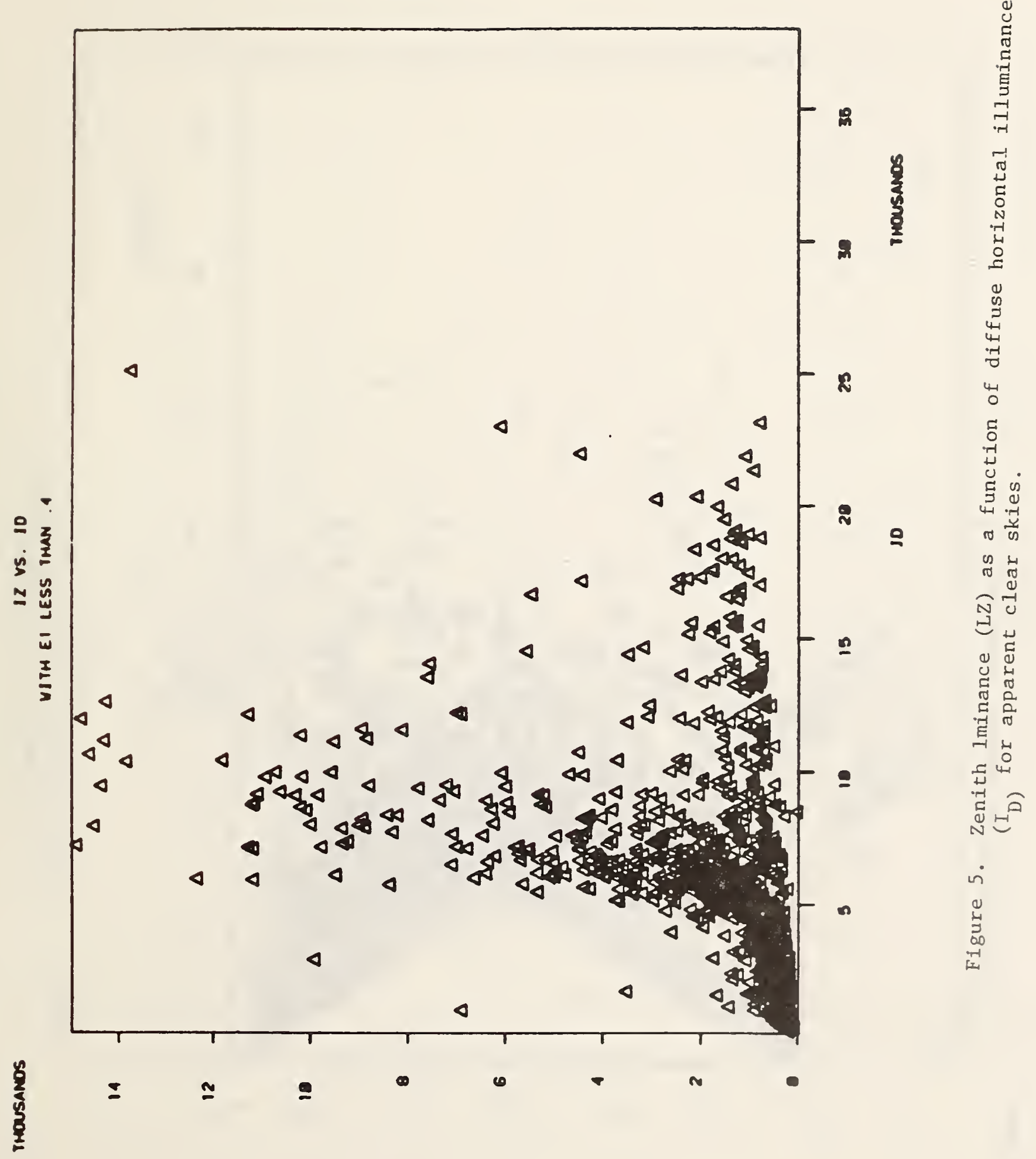




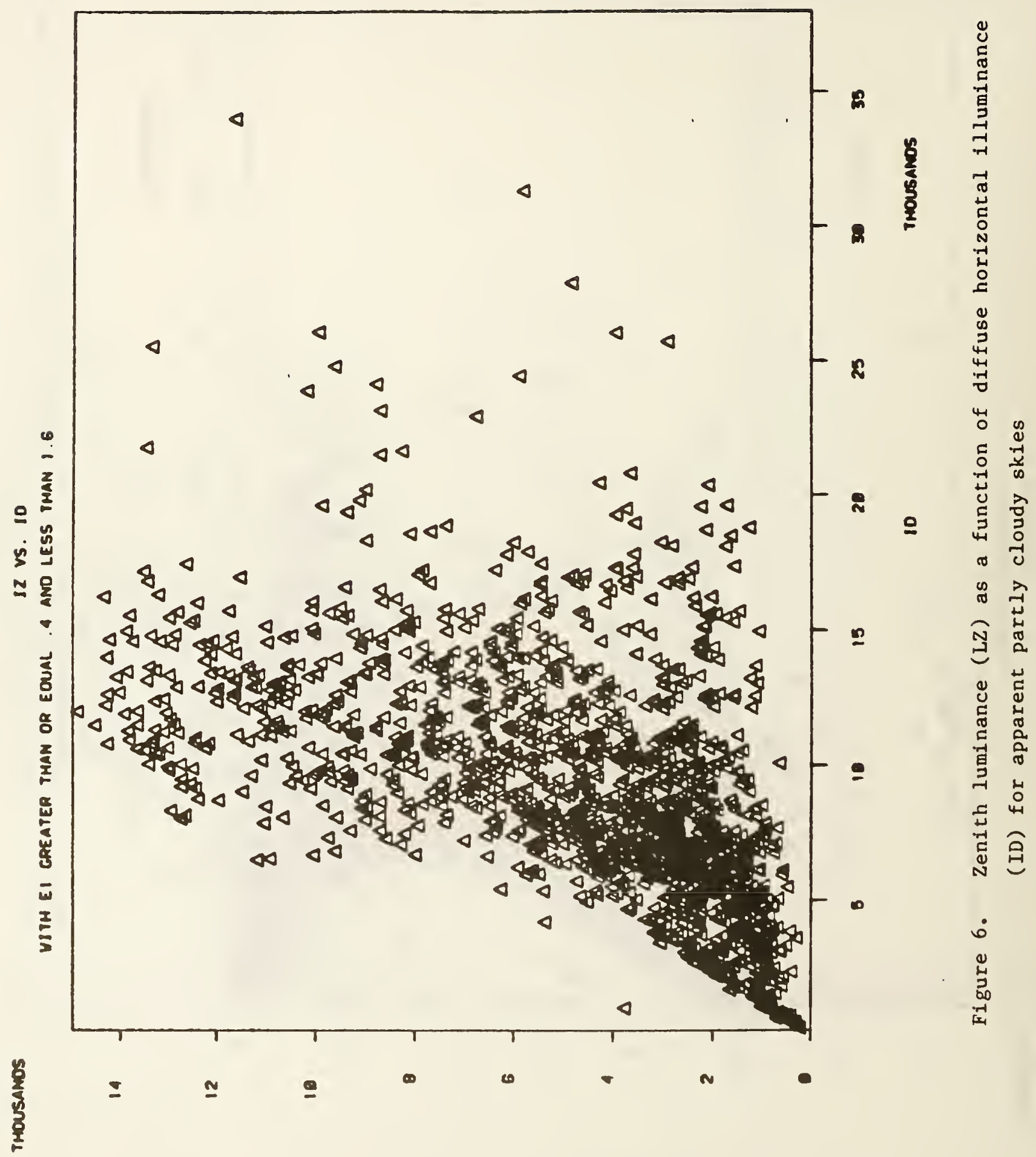




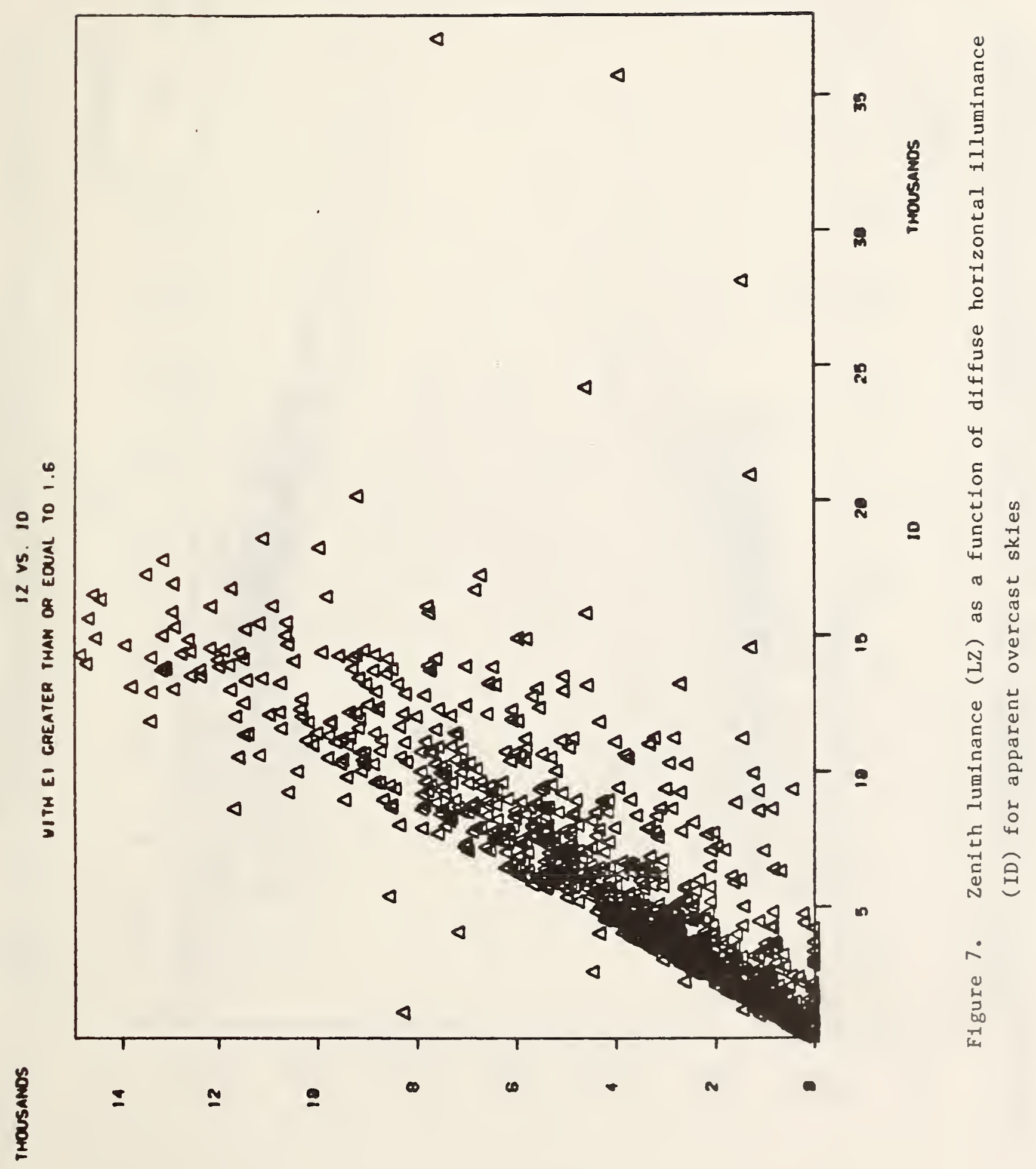




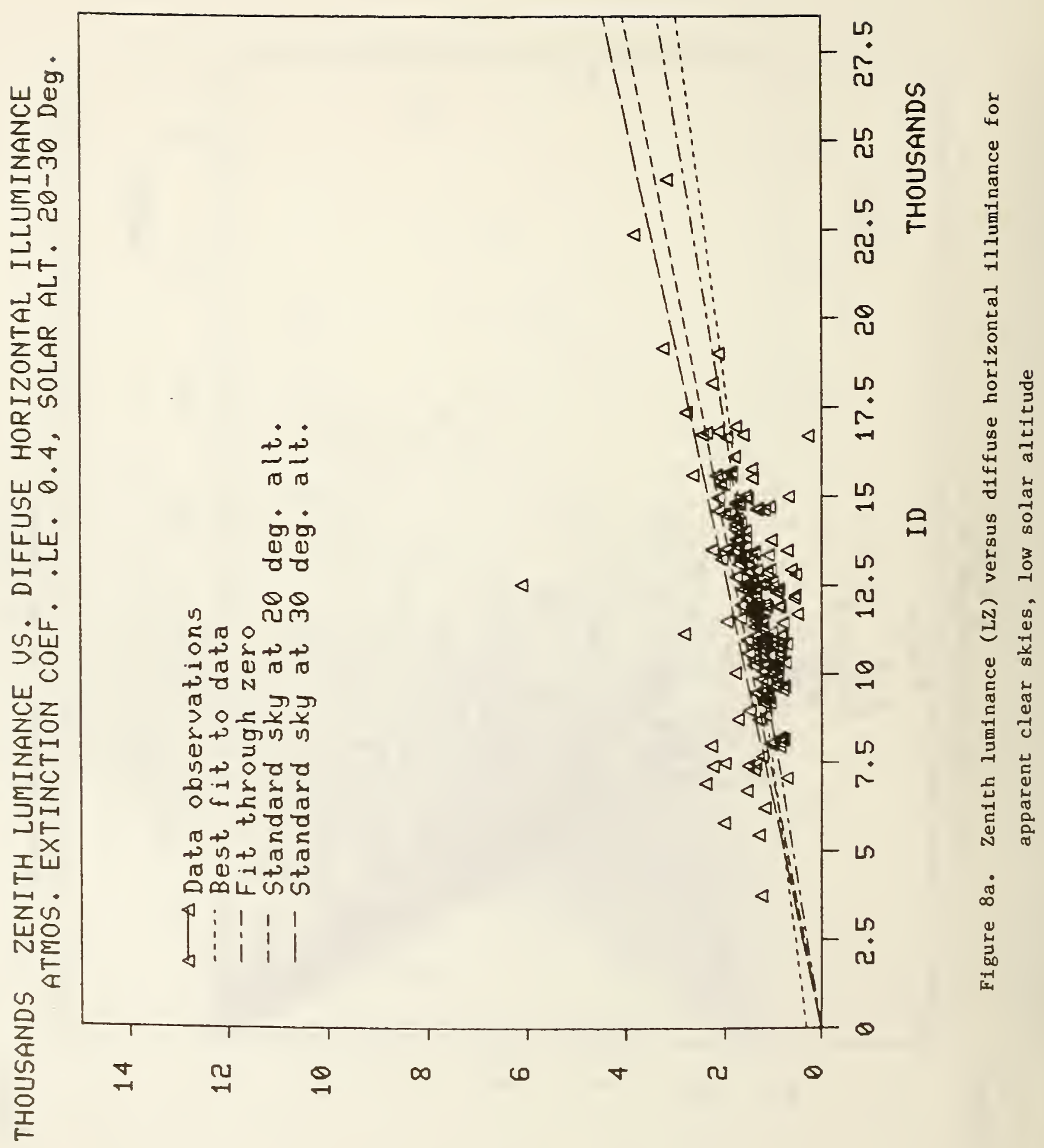




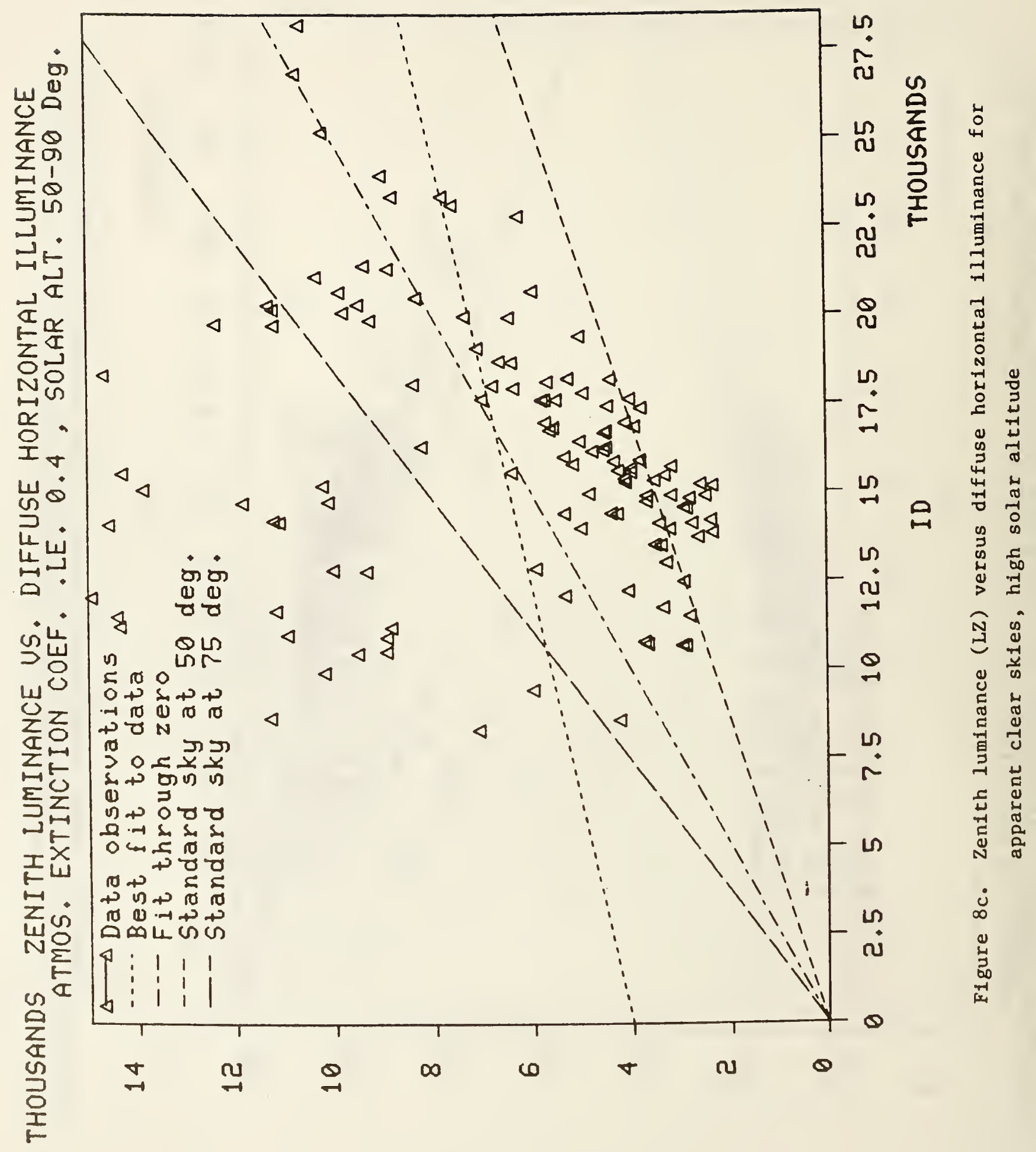




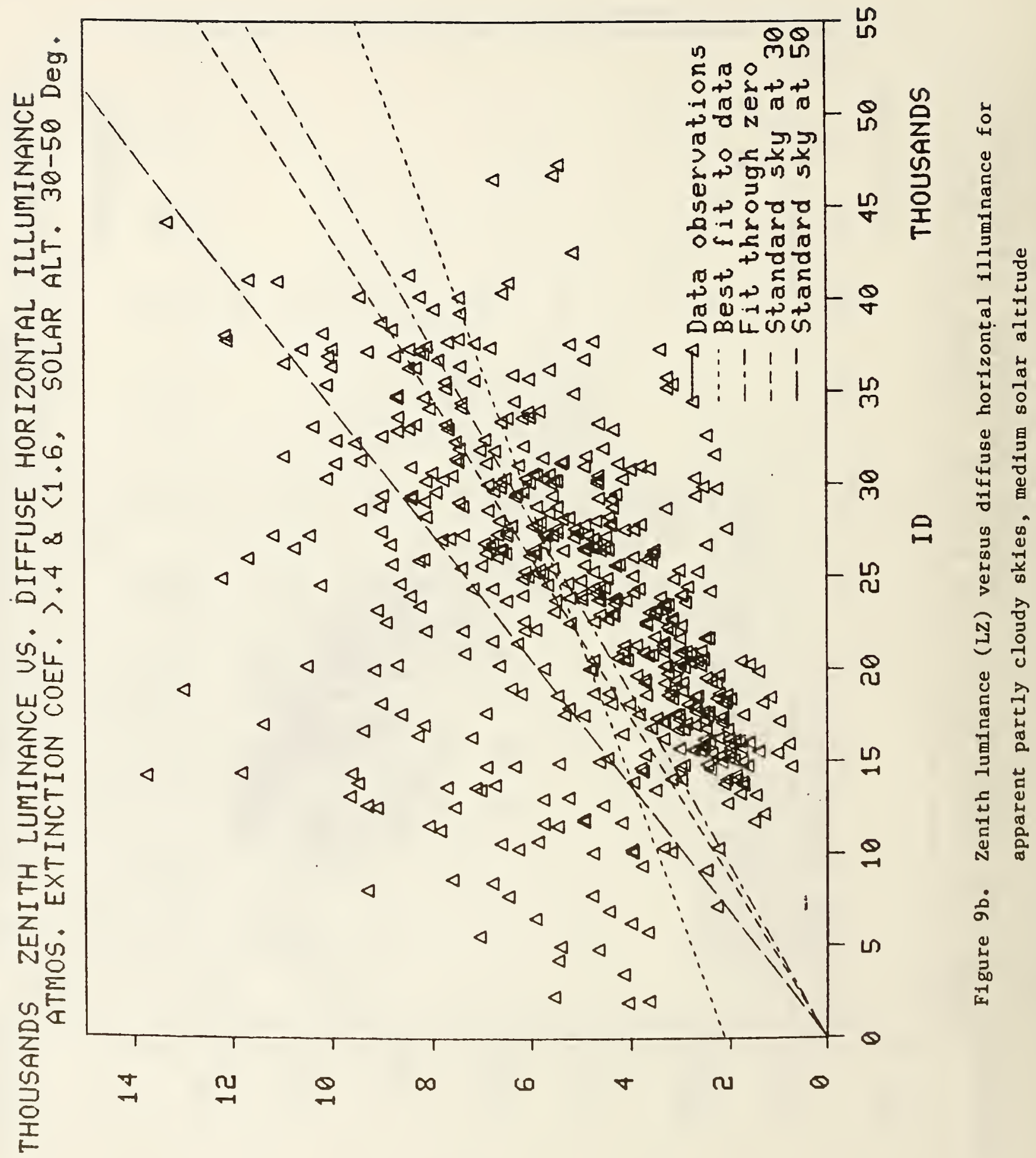









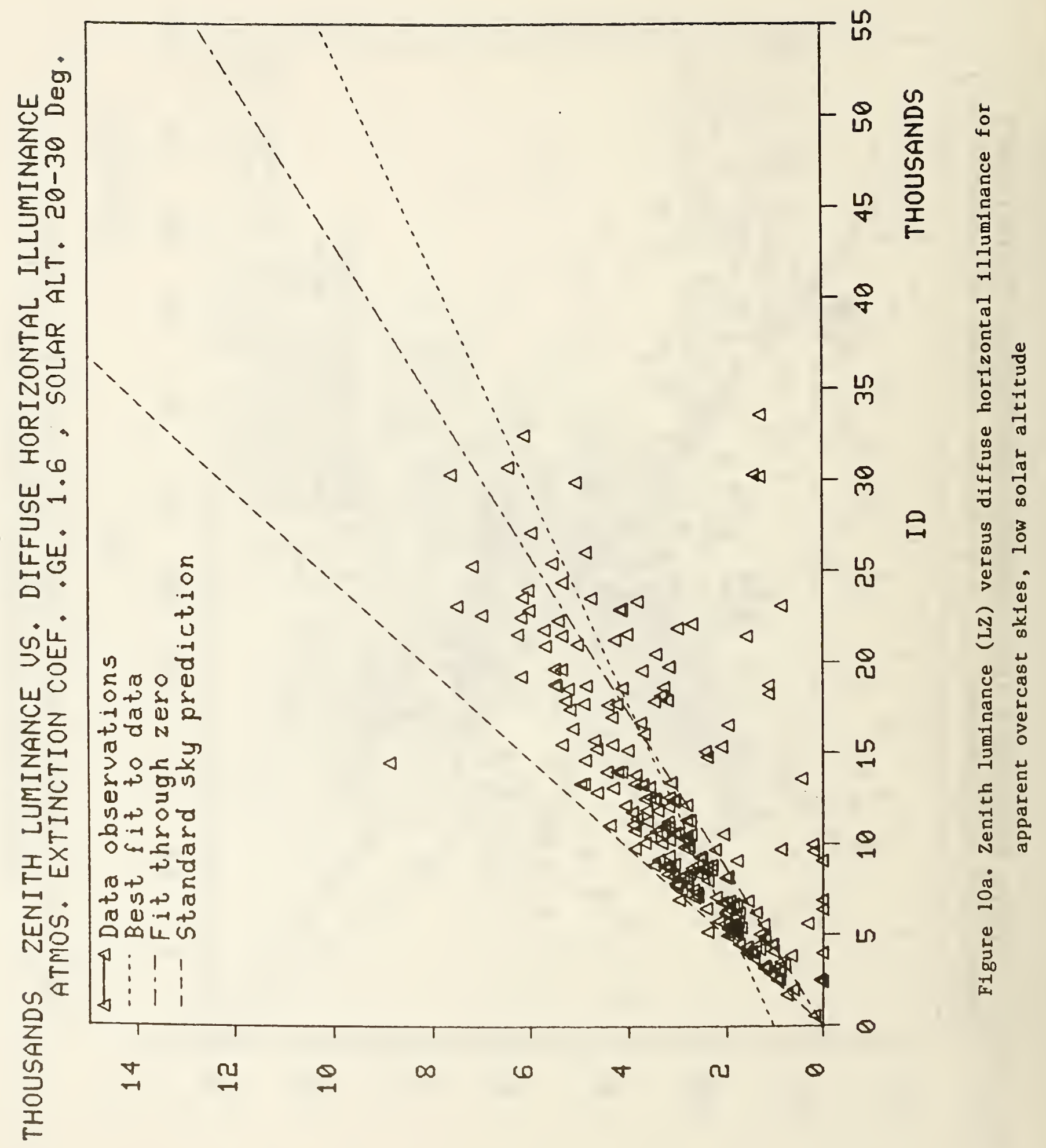




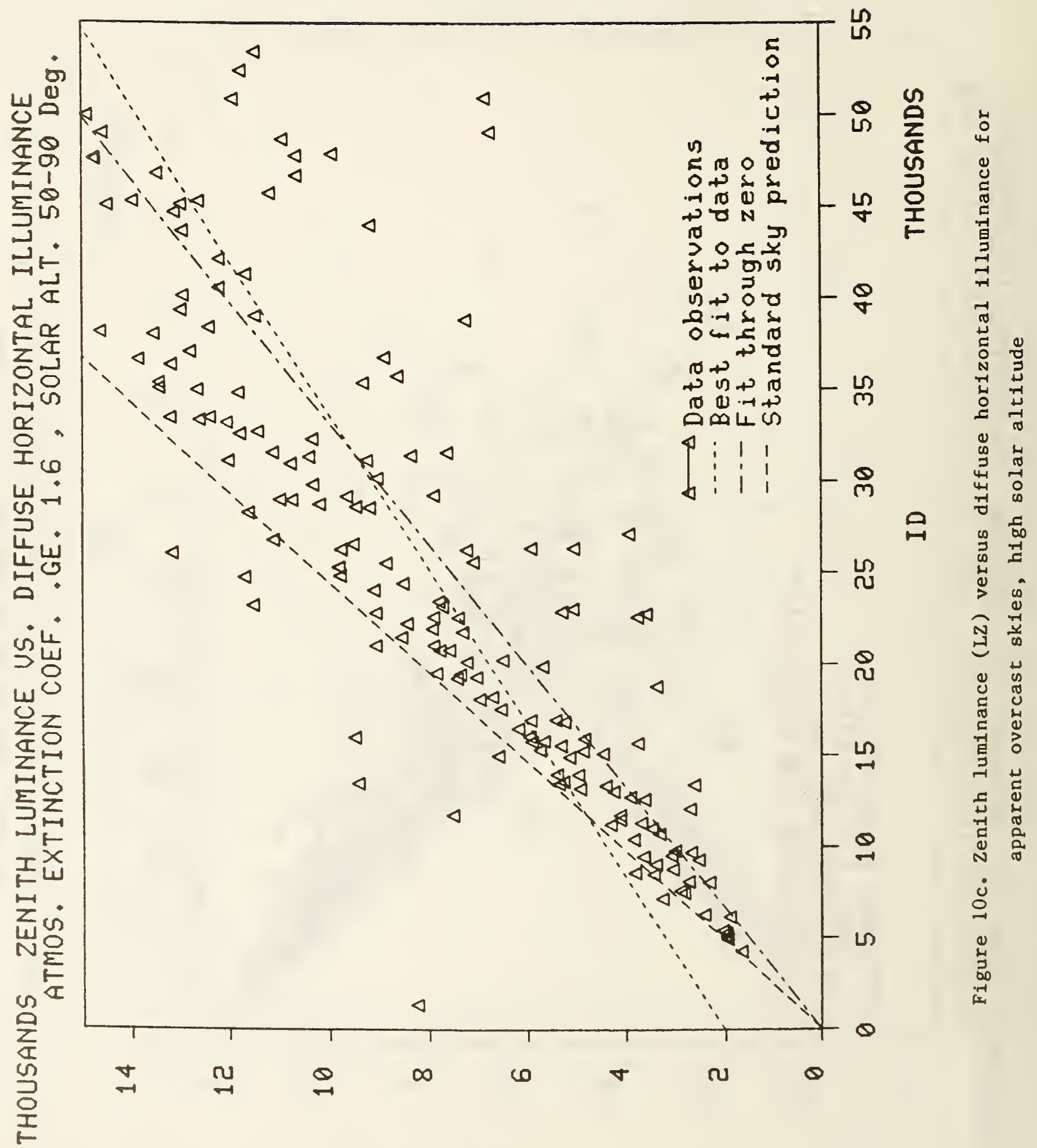




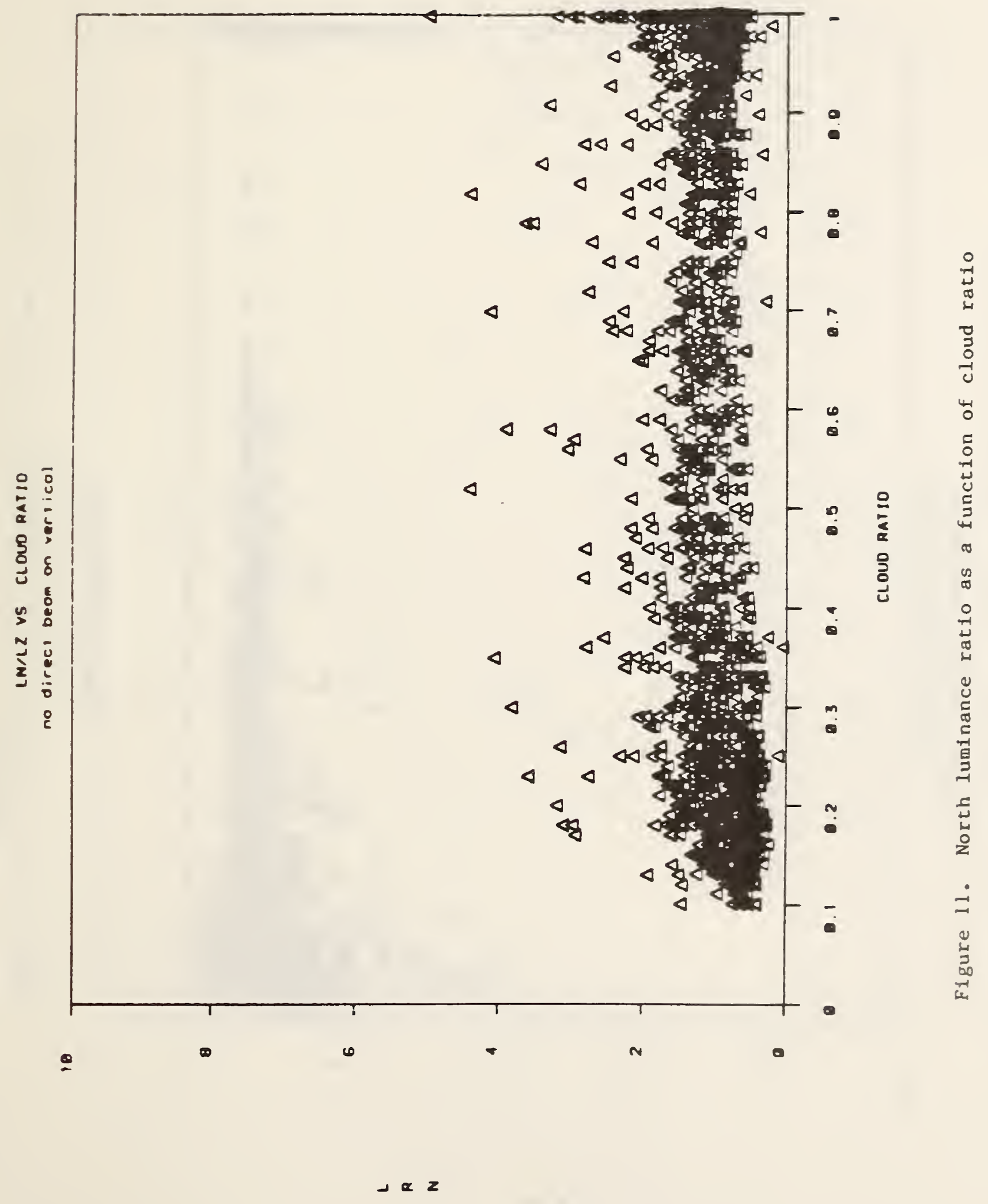




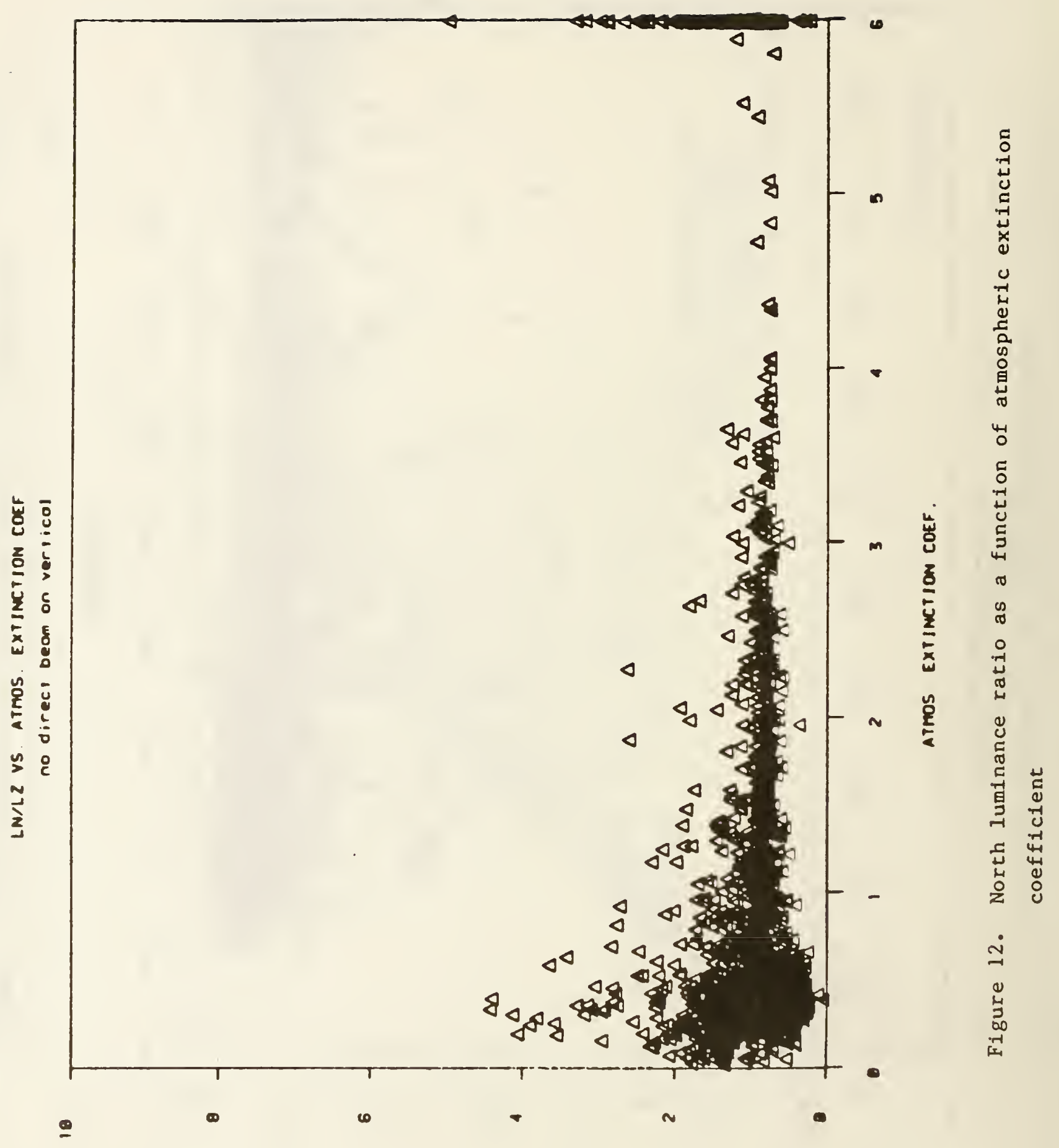




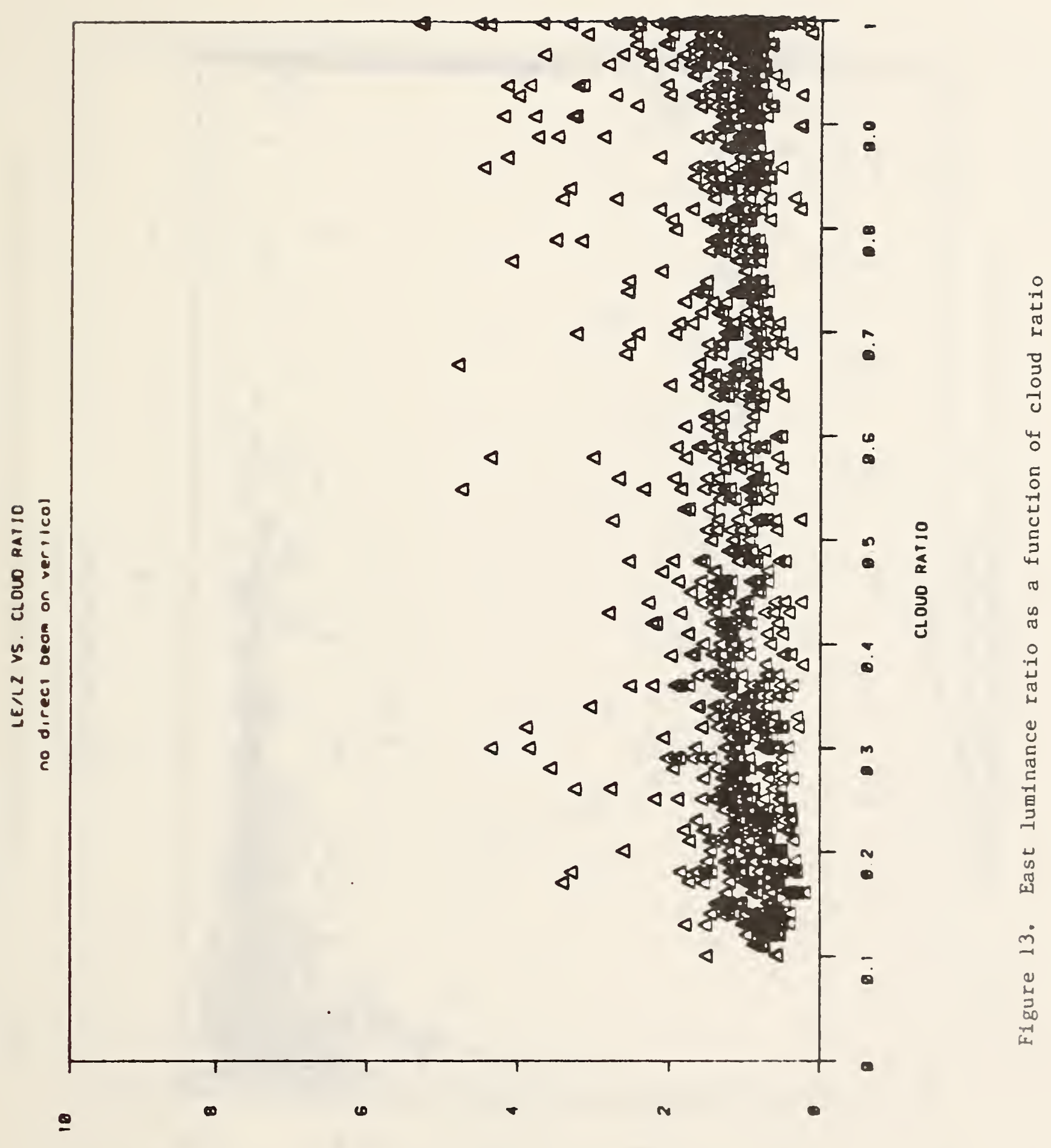




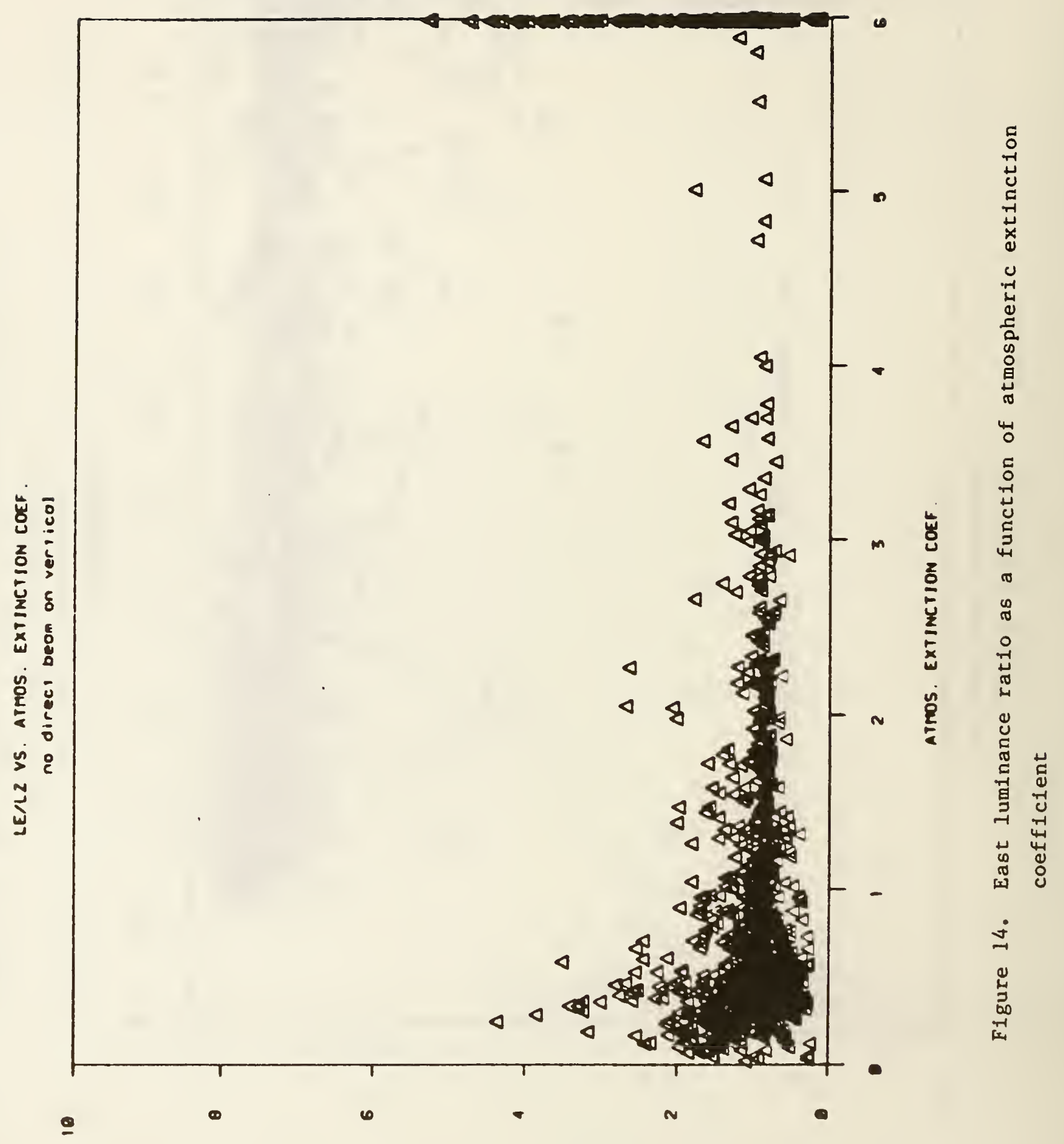




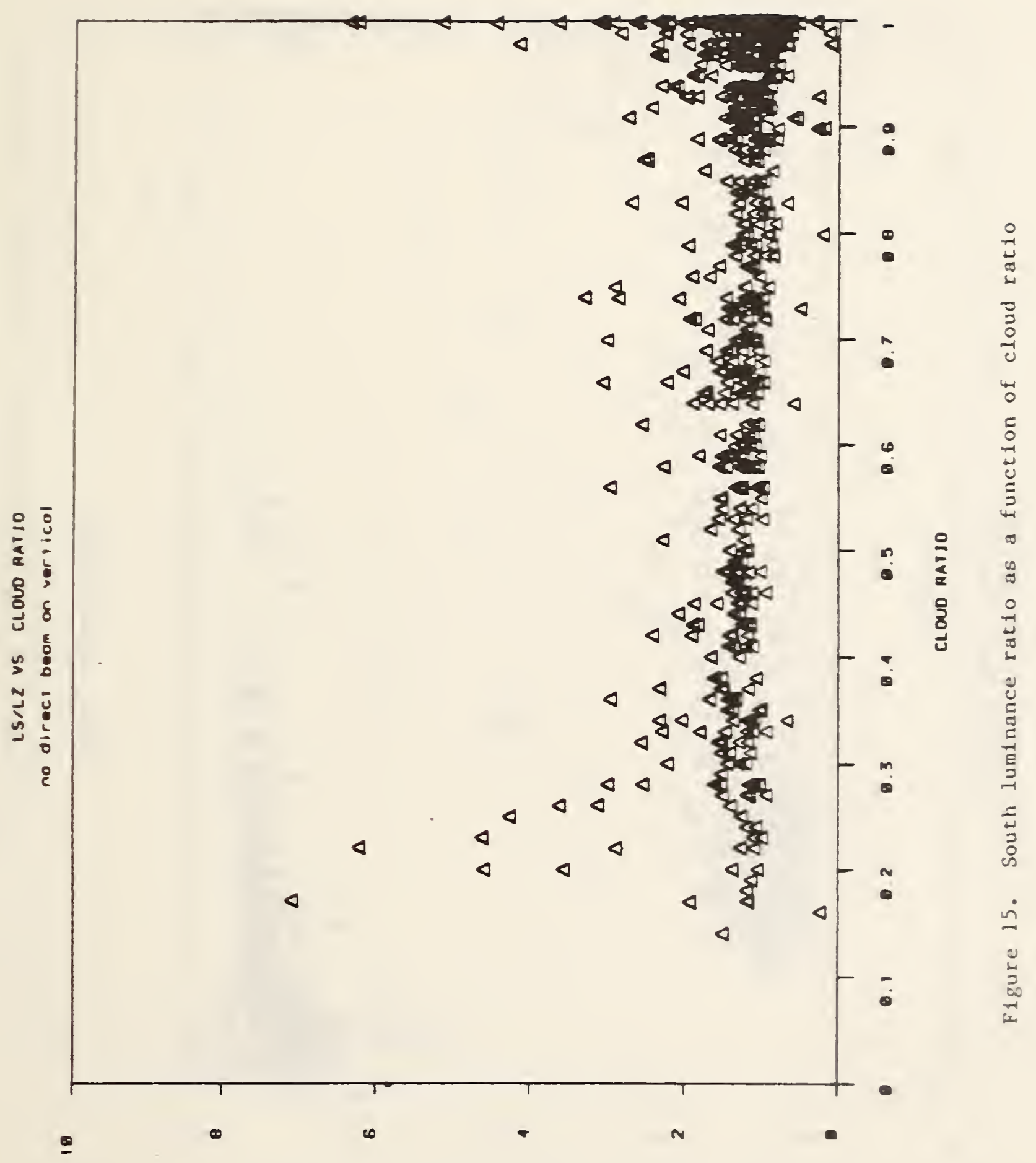




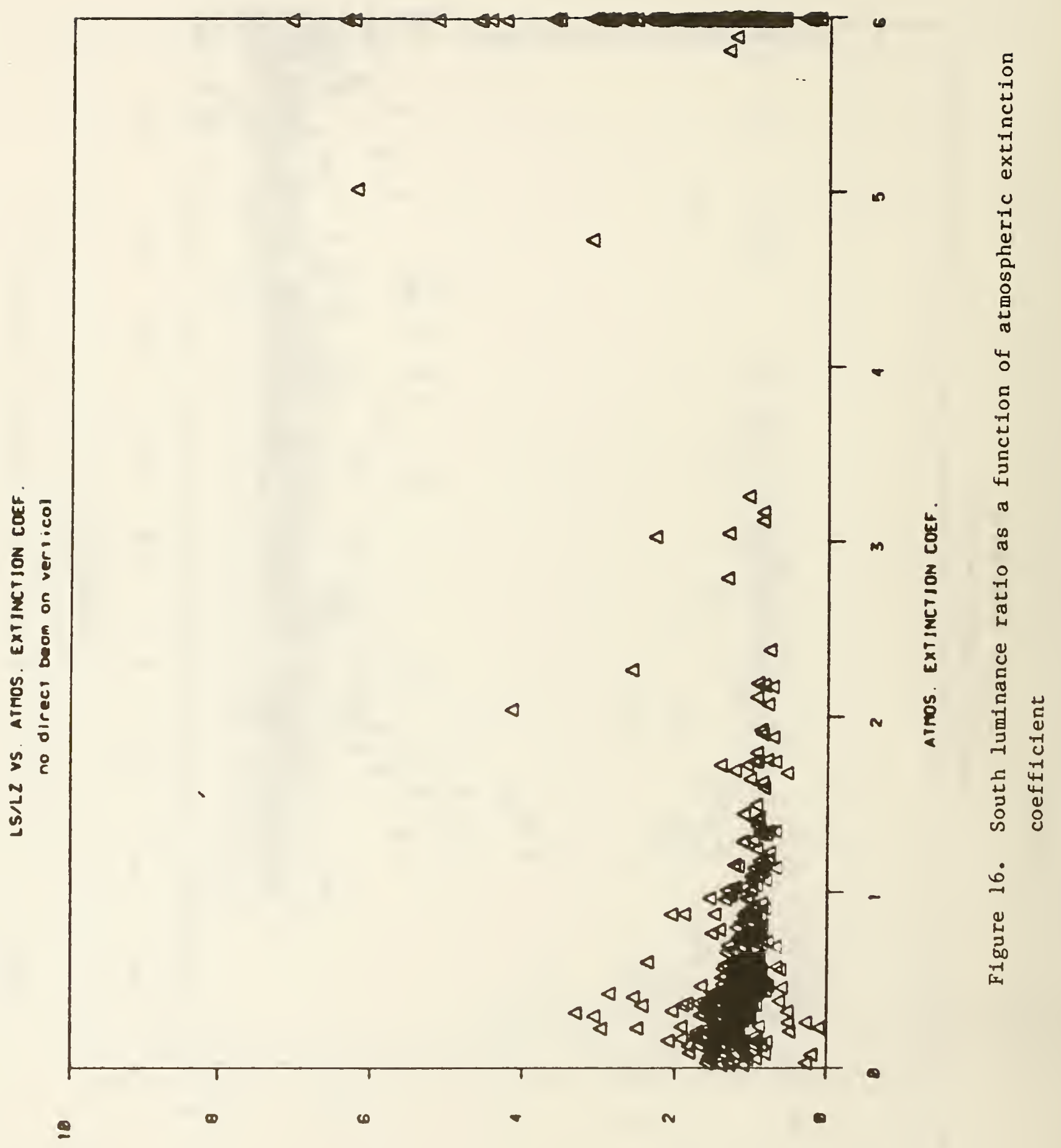




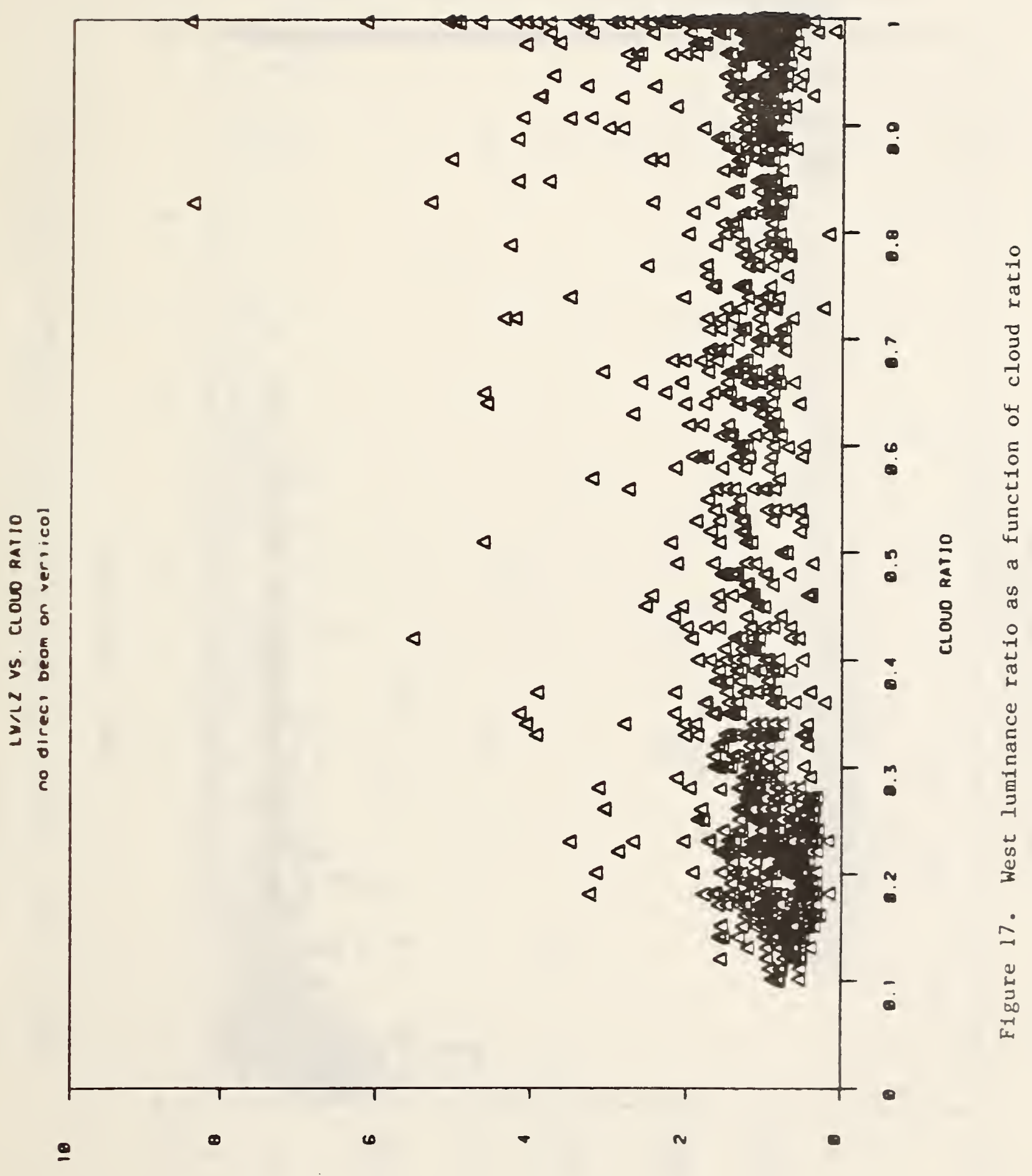




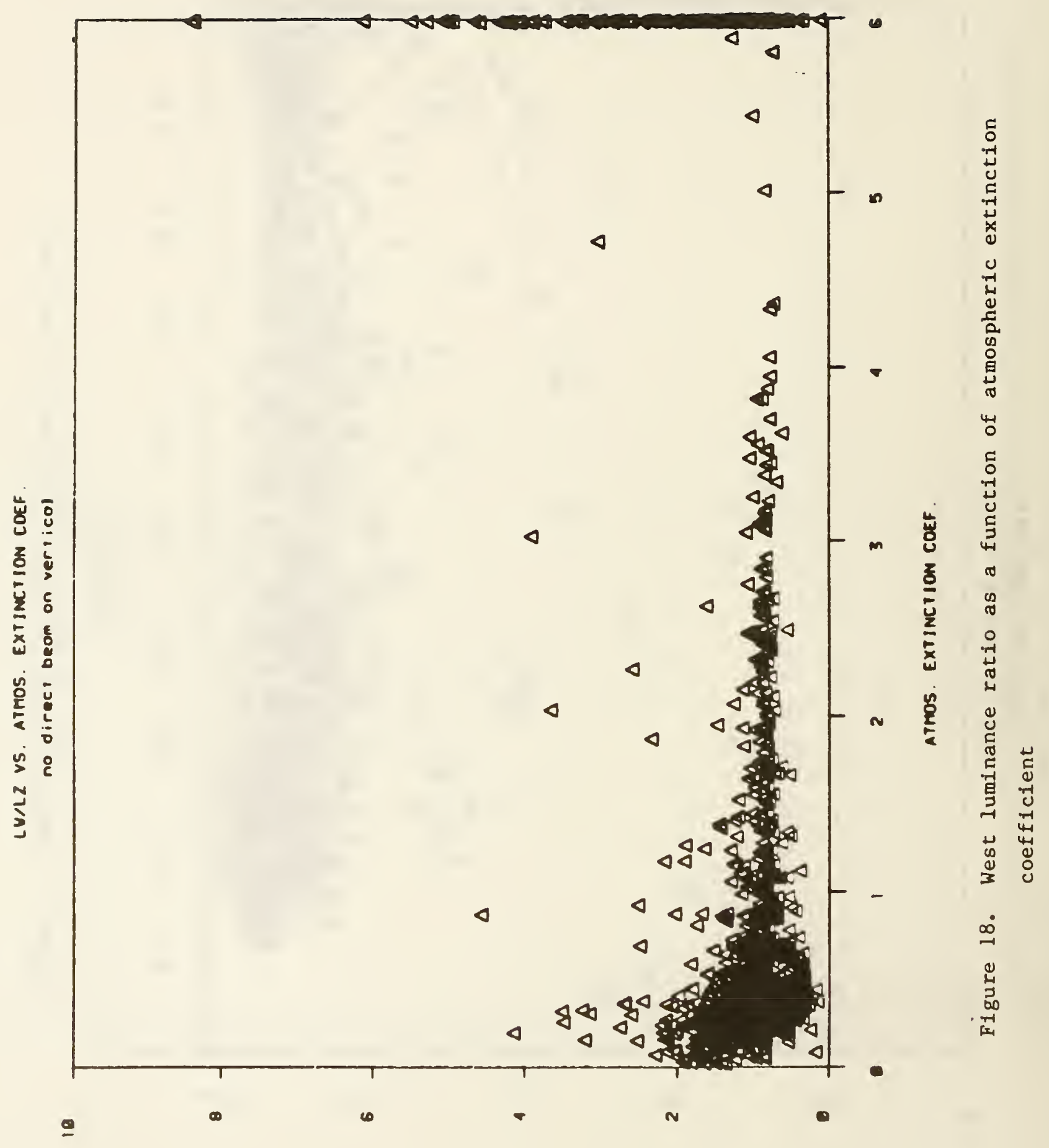




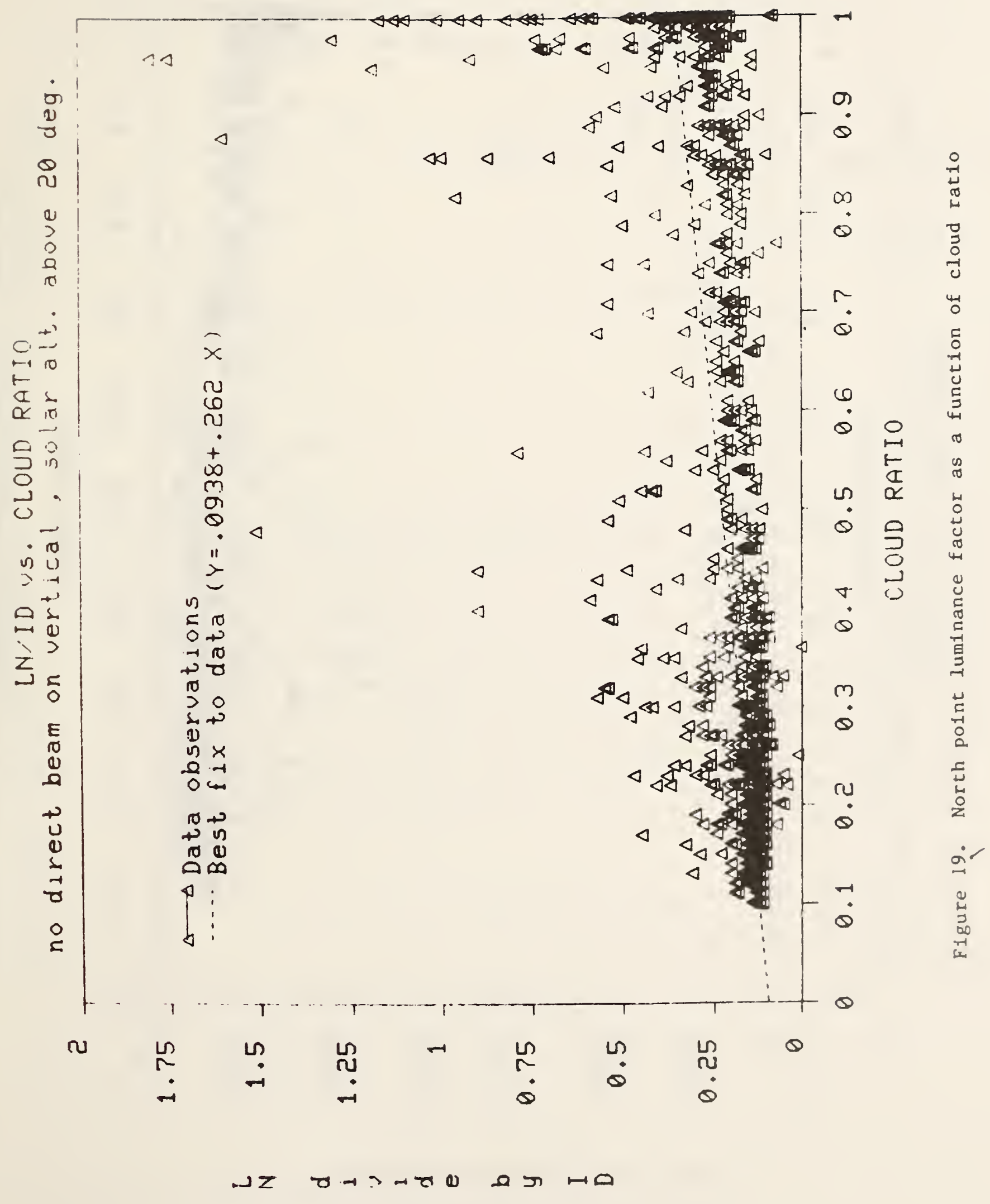




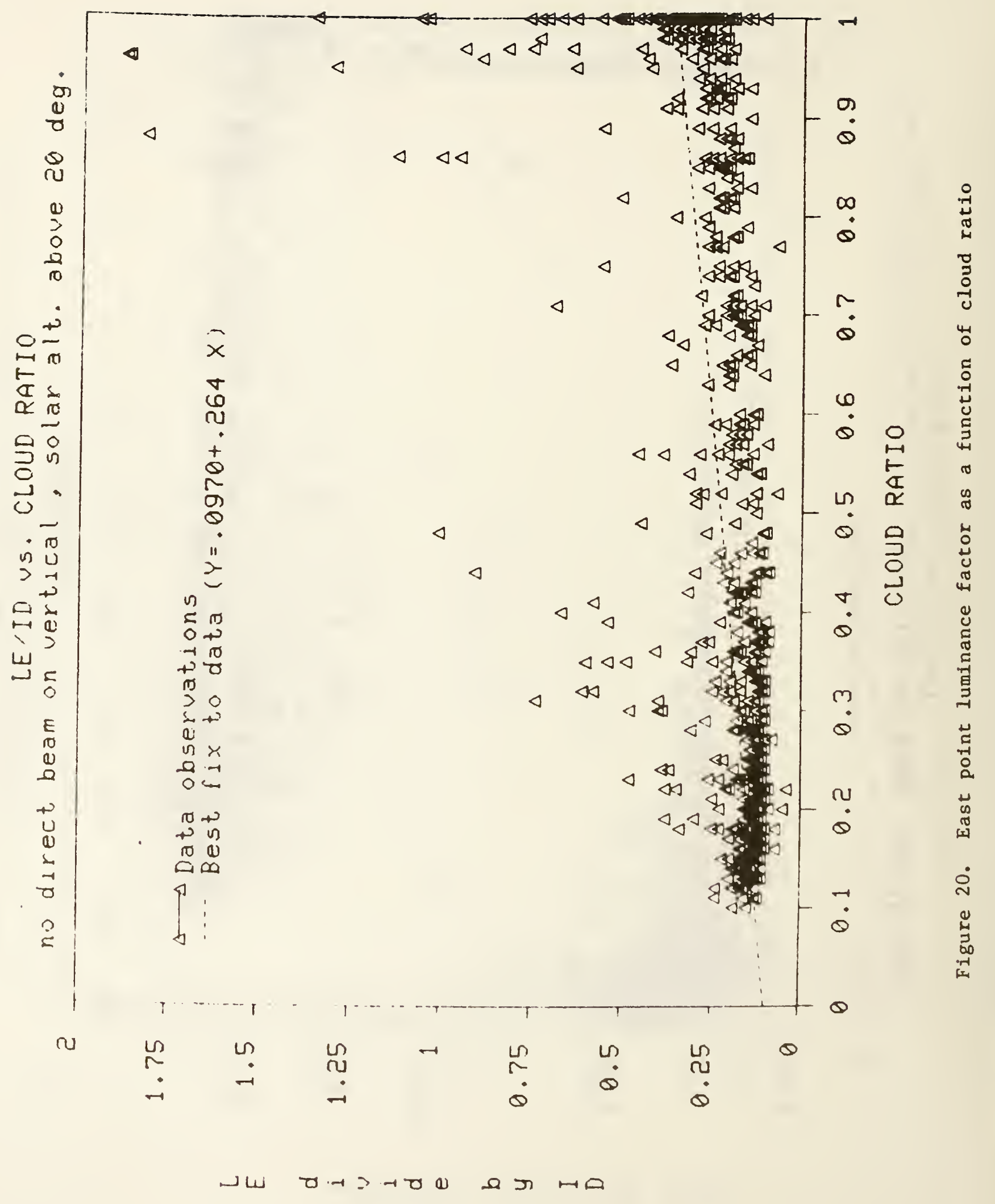




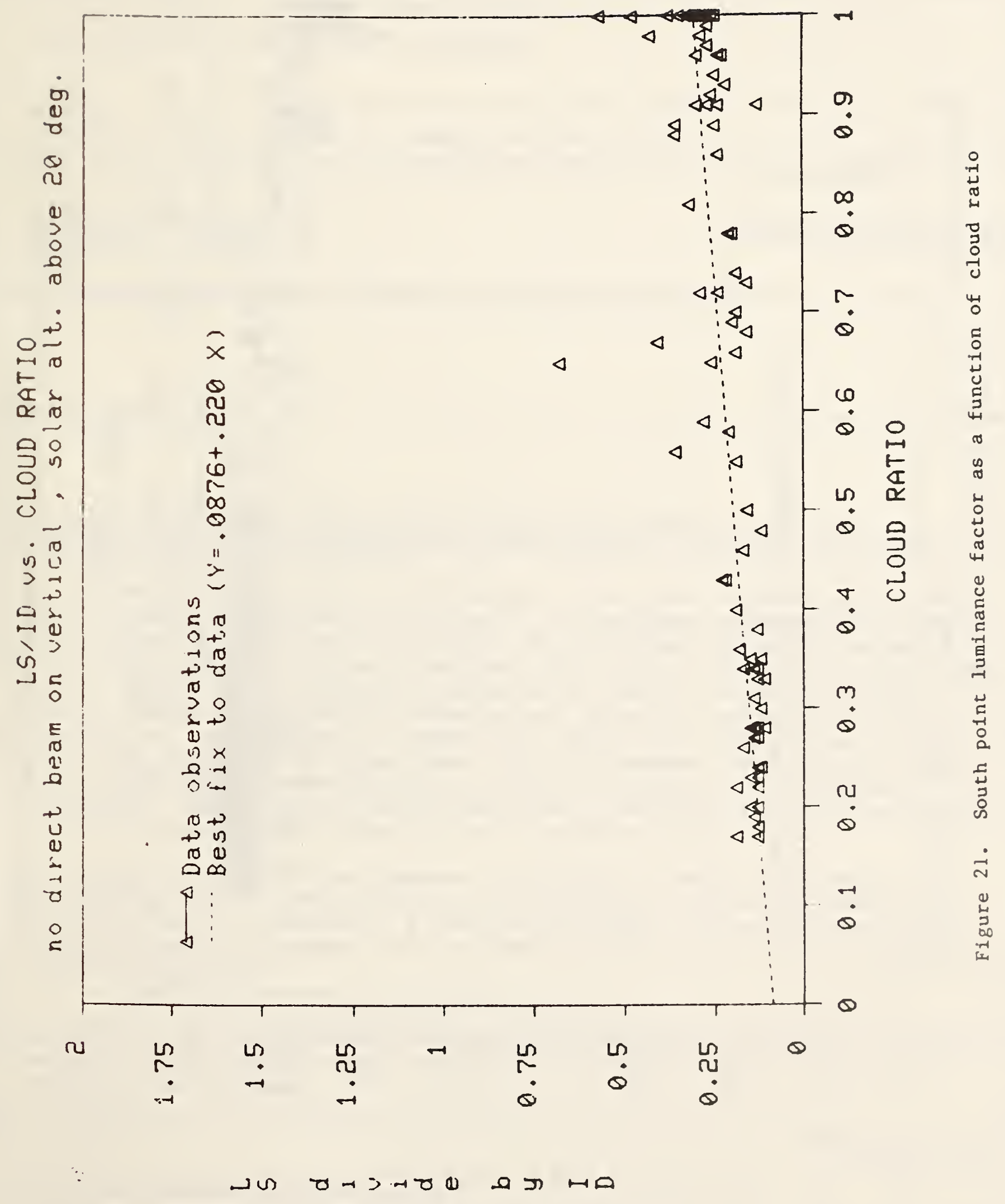




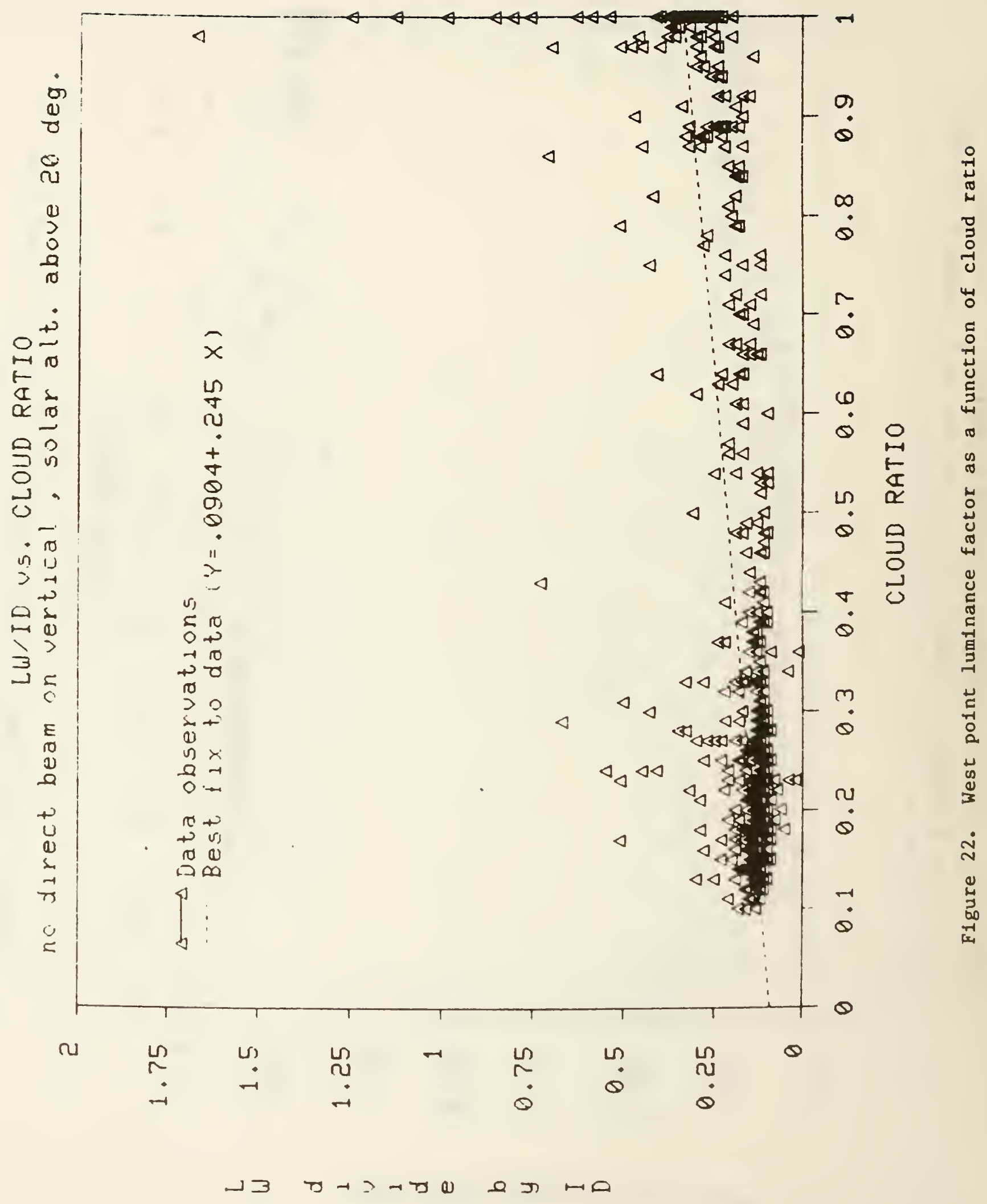


4. TITLE AND SUBTITLE

SKY LUMINANCE AND DIRECT BEAM ILLUMINANCE

5. AUTHOR(S)

Stephen J. Treado, William E. Remmert and John W. Bean

6. PERFORMING ORGANIZATION (If joint or other than NBS, see instructions)

7. Contract/Grant No.

NATIONAL BUREAU OF STANDARDS

DEPARTMENT OF COMMERCE

WASHINGTON, D.C. 20234

8. Type of Report \& Period Covered

9. SPONSORING ORGANIZATION NAME AND COMPLETE ADDRESS (Street, City, Stote, ZIP)

10. SUPPLEMENTARY NOTES

[] Document describes a computer program; SF-185, FIPS Software Summary, is attached.

11. ABSTRACT (A 200-word or less foctual summary of most significant information. If document includes a significant bibliogrophy or literoture sLrvey. mention it here)

Measurement of sky illuminance, sky luminance, direct beam illuminance and direct beam irradiance are analyzed and discussed. The database consisted of an annual set of integrated hourly measurements made at the National Bureau of Standards, Gaithersburg, Maryland ( $77^{\circ}$ west longitude, $39.5^{\circ}$ north latitude). The relationship between diffuse sky illuminance and luminance of selected portions of the sky dome is examined. Measured sky luminances are compared to luminance calculated using equations for three standard sky types-clear, partly cloudy and overcast. The percentages of diffuse and direct beam to total illuminance and irradiance incident upon a surface are presented for four vertical orientations and a horizontal orientation. This analysis enables evaluation of the relative daylighting potential of diffuse and direct daylighting and solar heating strategies.

The results indicate that the Iuminance distribution of actual skies varies considerably from the standard skies. The percentage of global illuminance which was direct beam was greatest for a south-facing surface ( 51 percent) and ranged from approximately 49 percent for a horizontal surface to less than 6 percent for a north-facing surface.

12. KEY WORDS (Six to twelve entries; olphobetical order; copitolize only proper nomes; and seporote key words by semicolons) Daylighting, diffuse radiation, direct beam radiation, 1lluminance, 1rradiance, luminance, sky condition.

13. AVAILABILITY

[X] Unlimited

$\square$ For Official Distribution. Do Not Release to NTIS

Order From Superintendent of Documents, U.S. Government Printing Office, Washington, O.C. 20402.

X Order From National Technical Information Service (NTIS), Springfield, VA. 2216I
14. NO. OF

PRINTED PAGES

50

15. Price 


